\title{
FDI in the Post-Soviet Space Three Decades after the Disintegration of the Soviet Union ${ }^{1}$
}

\author{
Kalman KALOTAY \\ Candidate of Economic Sciences (Hungarian Academy of Sciences), PhD (Corvinus \\ University, Budapest, Hungary); \\ Economic Affairs Officer \\ United Nations Conference on Trade and Development, Avenue de la Paix 8-14, 1202, \\ Geneva, Switzerland (retired on 1 September 2021); \\ Honorary Professor \\ Corvinus University, Fővám tér 8, 1093, Budapest, Hungary \\ E-mail: kalotayk@gmail.com \\ ORCID: 0000-0001-7349-9365

\section{Astrit SULSTAROVA} \\ PhD (The Graduate Institute, Geneva (IHEID), Switzerland); \\ Senior Economic Affairs Officer \\ United Nations Conference on Trade and Development, Avenue de la Paix 8-14, 1202, \\ Geneva, Switzerland \\ E-mail: astrit.sulstarova@un.org \\ ORCID ID: 0000-0002-6972-4942.
}

CITATION: Kalotay K., Sulstarova A. (2021). FDI in the Post-Soviet Space Three

Decades after the Disintegration of the Soviet Union. Outlines of Global

Transformations: Politics, Economics, Law, vol. 14, no 5, pp. 30-60.

DOI: 10.23932/2542-0240-2021-14-5-2

Received: 03.08.2021.

\begin{abstract}
The former Soviet Union disintegrated three decades ago. That momentous 1991 was not only the starting point for independence of the countries of the post-Soviet space but also the starting point for their transformation from centrally planned economy to capitalism, often with local specificities. At the moment of writing this article aiming at analysing the long-term, structural characteristics of
\end{abstract}

inward and outward foreign direct investment (FDI), these 12 economies are facing new COVID-19-related challenges, different from the problems of transformation undertaken in the past decades. After a brief literature survey, in which the main issues raised by academic research are highlighted, the article analyses the long-term trends and the main characteristics (geographical and sectoral) of FDI, with special reference

1 The views are those of the authors and do not necessarily reflect the opinion of the United Nations. 
to greenfield project announcements from 2003 on (the starting year of data availability). It also explores how much economic development was based on either attracting inward or promoting outward FDI or both. The performance of the 12 post-Soviet economies is controlled against the performance of other transition economies such as the Baltic States, South-East Europe and/or the Visegrad Group. The article concludes that indeed efforts towards using inward or outward FDI for development has been modest, even if in inflows one can observe some convergence with the other transition economies, which have been relying more wittingly using FDI for their development.

KEYWORDS: Inward FDI, outward FDI, transition, post-Soviet space, economic development.

\section{Introduction}

This article analyses the role of FDI in the economic development of 12 countries that emerged from the disintegration of the Soviet Union three decades ago ${ }^{2}$. To be noted that, in the analysis of the article, this group does not include the three Baltic States just as a control group for two reasons: 1. their divergent historical heritage: during the initial formative years of the Union of Soviet Socialist Republics (until World War II), they were independent non-socialist countries, and 2. their post-Soviet trajectory that brought them to EU membership in 2004. The analysis of the contribution of FDI is particu- larly important for a better understanding of how these economies reintegrated into the world economy after more than seven decades of centrally planned economy (with the exception of the Western regions of Belarus and Ukraine, the Kaliningrad Oblast of the Russian Federation, and the Republic of Moldova, which belonged to different countries - Poland ${ }^{3}$, Germany and Romania ${ }^{4}$, respectively - between the two World Wars.)

Thirty years are already a sufficiently long trajectory to allow us to draw conclusions about the long-term characteristics and the role of both inward and outward FDI in the development of the 12 countries in question. In particular, who wish to know if these countries have relied more or less on inward and outward FDI than the rest of the world, and if they have they performed better or worse than other countries. If there is a significant difference, is better performance positively or negatively correlated with reliance on inward and/or outward FDI?

A long-term view is also required because the post-Soviet group has been prone to a series of crises since the dissolution of the Soviet Union, and it is not easy to disentangle the effects of disintegration from the effects of transition to a market economy. We also note that the economic cycles of the 12 countries often moved together in the post-Soviet period. The list of recessions included:

- The transition-related decline starting in 1991 and ending at different times: in 1993 in Armenia, in 1994 in Georgia, in 1995 in Azerbaijan, Belarus,

\footnotetext{
2 Armenia, Azerbaijan, Belarus, Georgia, Kazakhstan, Kyrgyzstan, the Republic of Moldova, the Russian Federation, Tajikistan, Turkmenistan, Ukraine and Uzbekistan. This study does not cover those territories that self-declared independence but have not been recognized by the international community as members of the United Nations. This study uses national statistics without taking position on eventual territorial disputes among the 12 countries analysed. The term post-Soviet economies is used in order not to pre-judge the self-designation of the 12 countries in terms of their belonging to any given country group.

3 With the exception of the Zakarpattia Oblast of Ukraine that belonged to Czechoslovakia and Hungary between the two World Wars.

4 The current internationally recognized borders of the Republic of Moldova are in part different from that of the territory that belonged to Romania between 1918 and 1940: they include Transnistria but exclude Budjak.
} 
Kazakhstan, Kyrgyzstan and Uzbekistan, in 1996 in the Republic of Moldova, the Russian Federation and Tajikistan, in 1997 Turkmenistan. In Ukraine, the recession lasted till 1999.

- The first Russian financial/economic crisis in 1998 (also called ruble crisis or the Russian flu), which also affected growth in Kazakhstan and the Republic of Moldova.

- The Global Financial Crisis of 20082009 that affected the majority of the 12 post-Soviet economies, especially in 2009.

- The second Russian financial/currency crisis (ruble crisis) of 2014-2016 that also affected the other post-Soviet economies in Europe and in the Caucasus (but less in Central Asia).

- The COVID-19 crisis started in 2020 causing negative growth in all post-Soviet countries. The end year of the crisis in unknown but it is projected to affect FDI at least till the end of 2021 [UNCTAD, 2021].

There is also a need to consider two additional factors which has affected the stability of both inward and outward FDI largely. One of them is the political turbulences of various post-Soviet countries, which is often related to their nascent statehood and unresolved internal conflicts. Without being exhaustive, it is necessary to mention the Tajikistani Civil War in 1992-1997, the Nagorno-Karabakh wars, the Euromaidan in Ukraine with its international consequences, other changes of governments due to street protests in Georgia, Kyrgyzstan, the current protests in Belarus etc. The other factor is international politics. It is related to the international relations of post-Soviet countries with the rest of the world. One is the cycle of relations with the Euro-Atlantic world (NATO, EU). In general, they underwent a détente after the dissolution of the Soviet Union but deteriorated largely from 2014, with the onset of the Crimean and East Ukrainian crises (cf. [Kalotay, 2014]), leading to sanctions and counter-sanctions, as well as stricter screening and merger control rules in the EU and the United States. These developments affected negatively both inward and outward FDI. Another major aspect of the global politics affecting FDI in the post-Soviet space is its relationship with China and its Belt and Road initiative. The bulk of post-Soviet countries are located on the ancient Silk Road and are participants of the current-day initiative. This leads to both cooperation and rivalry between local/intraregional and Chinese business interests; however, given the complementarities between China and the post-Soviet partners, the links between the two usually increase FDI links.

This article recognizes the complexities of the post-Soviet space and focuses on the long-term trends, looking beyond the shorter-term instabilities. It can be assured through various ways. One is to analyse a longer period of series and detecting the trendlines. The other possibility is to combine the analysis of FDI flows with the analysis of FDI stocks. The latter are more stable, although they also show some fluctuations in deep crisis years due to changes in exchange rates and valuation of corporate assets.

The rest of the article is organized as follows. The next section offers a bird's eye view of the main findings of the extant literature, followed by a presentation of the main trends. The subsequent section estimates the role of inward and outward FDI, followed by a concluding section, looking into the prospects of FDI in the post-Soviet group.

\section{Literature: the main issues}

The role of inward and outward FDI in the transition from centrally planned to market economy - and in the economic 
development of those transition economies in general - has been an intriguing topic for academics for some time. In this literature, China and the Chinese case has attracted the bulk of attention. Compared with that, the so-called former Eastern bloc received less attention and, even within that literature, the focus has been on either the "early bird" transformers (Czechia, Hungary, Poland) or large economies such as the Russian Federation. It has been noted that literature is especially scarce in the former Soviet periphery, such as Armenia, Georgia, Kyrgyzstan, Moldova, Tajikistan and Turkmenistan [Kalotay, (1) 2013]. There are some studies that deal with FDI in larger post-Soviet economies either in their own right or their relationship with other post-Soviet economies, especially the Russian Federation: For some examples of exceptions, see: [Kononov, 2010, Kvashnin 2018] on Ukraine, [Petrushkevich, 2010; Shmarlovskaya, Petrushkevich, 2010] on Belarus, [Balakishi, 2020] for the South Caucasus. In some cases, the study of FDI is embedded in the analysis of economic relations with the Russian Federation in general. For the case of Kazakh-Russian relations, see [Zabortseva, 2014].

The unevenness of literature is a bit unfortunate because, going beyond the perception that the countries centrally planned economies used to form a single bloc, there may be major differences between individual countries worth analysing separately or by subgroups. This variety is to be kept in mind also when studying the case of the 12 countries that emerged from the dissolution of the Soviet Union. For example, they may be differences between the five members ${ }^{5}$ and the seven non-members of the Eurasian Economic Union (EAEU) and the four mem- bers of the "Western"-oriented GUAM Organization for Democracy and Economic Development ${ }^{6}$ due to their divergent international political orientation.

As for the role of FDI, one of the early studies [Kalotay, 2001] hypothesized that, due to the lack of local entrepreneurs and local capital, inward FDI would play a more important role in transition than outward FDI. The early bird countries, the Baltic States and South-East Europe seemed to follow this prediction, which was in line what the investment development path would predict [Dunning, 1981; Dunning, 1986]. However, even in this group there were differences, and the Russian Federation followed a different trajectory, in which inward and outward FDI played an almost equal role (cf. [Kalotay, Sulstarova, 2010]). There was therefore a need to rethink the inward-outward FDI nexus (for a systematic analysts, see [Kuznetsov, 2007]).

There are various ways to categorize the literature on FDI in the post-Soviet space, which, in the majority of cases, focused on the Russian Federation, and on its fast rising outward FDI. Our summary, however, intends to indicate the studies dealing with the question of inward FDI, too. We would focus on those centres of studies, which have been particularly active in the analysis of post-Soviet FDI. In most cases, these centres involved a network of researchers, oftentimes co-authoring the papers. Nevertheless, these centres have also had some coordinating persons, whose names are also to be mentioned as the leaders and catalysts of activities.

The Finnish centre of research has been active since the mid-1990s, led by Kari Liuhto, first from Lappeenranta, then from Turku (cf. [Kuznetsov, 2009]). It has mobilized research from all around the world, and both from the Russian Federation 
and the international research community, providing a platform for exchange between inside and outside views on FDI in post-Soviet transition. It also published general information materials on less known transition economies, too. It was also one of the initiators of monographies on the role of outward FDI in the Russian economy [Liuhto, 2006] and on the role of FDI in the Russian economy in general [Liuhto et al., 2017]. It was also among the first centres of study that drew attention to the problem of transhipped and roundtripped FDI via Cyprus [Pelto et al., 2004] and the impact of sanctions on FDI flows (cf. [Liuhto, 2015]). It was also among the first ones to monitor the activities of the largest Russian multinationals (cf. [Vahtra, Liuhto, 2006]).

The Austrian centre of research on transition economies - the Vienna Institute of International Studies (wiiw) - has traced the FDI flows of transforming economies from the beginning, with a special focus on Austria's neighbours. Over time, it has expanded its scope to the Balkans, the Baltic States and to various post-Soviet economies: Belarus, Kazakhstan, the Republic of Moldova, the Russian Federation and Ukraine. For its most recent study on the impact of the COVID-19 crisis, see [Adarov, Hunya, 2020]. The Institute has also produced analytical materials on the impact of FDI, also in the Russian Federation (cf. [Hunya, 2008]).

In the Russian Federation, a large network of researchers has also produced major studies on inward and outward FDI in the country - and also some other post-Soviet economies. In the monitoring work, a leading role was played by Alexey Kuznetsov. In these studies, in the majority co-authored by various researchers, the focus was on mutual investment among the countries of the Commonwealth of Independent States [Kuznetsov, 2013; Kuznetsov et al., 2012; Kuznetsov et al., 2013; Kuznetsov, (1) 2014; Kuznetsov, (2) 2014] and in the EAEU [Kuznetsov et al., 2017]. This monitoring prompted studies on the role of FDI in Eurasian integration [Kuznetsov, 2016] and relations with the European Union [Kuznetsov, (2) 2010]. Studies dealt with both inward FDI (cf. [Kuznetsov, (1) 2010; Kuznetsov, 2012]) but more often with outward FDI [Bulatov, 1998; Bulatov, 2017; Kuznetsov, 2009; Kuznetsov, 2011; Kuznetsov, 2021]. In addition, multi-authored monographies analysed various aspects of capital exports form the Russian Federation [Bulatov et al., 2015; Bulatov et al., 2019].

In St. Petersburg, research focused on Russian outward FDI, corporate strategies and policy issues. Andrei Panibratov played a leading role in preparing monographies (e.g., [Panibratov, 2012]), articles on home country and State influences [Panibratov, 2016; Panibratov et al., 2015; Panibratov, Michailova, 2019] and the internationalization strategies of Russian multinationals [Kalotay, Panibratov, 2013; Dikova et al., 2019].

From a global perspective, the Division on Investment and Enterprise of the United Nations Conference on Trade and Development (UNCTAD) and its predecessors $^{7}$ have been the focal points for the analysis of FDI in the whole UN system and for more than four decades. It started its in-depth research on economies in transition in the early 1990s (see [United Nations, 1992]). It has been in close cooperation with the other centres, catalysing their research, and also providing the global context to the analysis of those centres. It has provided its analysis in the World Investment Report series since 1991, and its

\footnotetext{
7 The United Nations Centre on Transnational Corporations (1975-1992) and the Transnational Corporations and Management Division of the United Nations Department of Economic and Social Development (1992-1993).
} 
staff also participated in the international debate on post-Soviet $\mathrm{FDI}^{8}$. Its academic journal, Transnational Corporations, published articles by researchers from the international centres [Bulatov, 1998; Bulatov, 2017; Liuhto, Vahtra, 2007; Kuznetsov, (2) 2010] and related researchers (e.g., [Tepavcevic, 2015]).

It has to be stressed that the analysis of inward and outward FDI in the post-Soviet space is a global research interest and there are many other universities and research centres that have made valuable contribution but could not be mentioned in order to keep this summary brief. However, a common feature is that these researchers are in close cooperation with the centres mentioned and with UNCTAD, whether they work at the UNU in Maastricht (e.g., [Filippov, 2008; Filippov, 2011; Filippov, 2012]), Hungary (e.g., [Tepavcevic, 2015; Weiner, 2018; Weiner, 2020]), or France (e.g., [Andreff, 2011; Weiner, 2015; Andreff W., Andreff M., 2017]). To be noted that global studies often analyse the Russian case together with the other BRICS: Brazil, China and India (cf. [Sauvant, 2006; Andreff, 2015]).

A common thread of the literature on post-Soviet FDI is that it is difficult to gauge its impact on economic transformation and development. First of all, the authors of these lines are not aware of any study going into the impact of outward FDI. Liuhto and Majuri prepared a very comprehensive review of more than 100 articles on Russian outward FDI, which dominates outflows from the region, but have not found comprehensive studies on the development impact [Liuhto, Majuri, 2014].

As for the role of inward FDI, the first in-depth study on the impact of economic growth [UN.ECE, 2001] already found that the effects may be ambiguous, less pronounces in post-Soviet countries than EU membership candidates and dependent on good policies. To be noted that in terms of policy transition, post-Soviet economies have been laggards compared with the frontrunners such as Czechia, Hungary or Poland, or even the Baltic States. To demonstrate the disagreement between analysist about the macroeconomic impact of FDI, some of the studies (e.g., [Okafor, Webster, 2016]) have found an overall positive impact of FDI on economic growth, while others (e.g., [Curwin, Mahutga, 2014]) have found a negative impact. There have been also studies that focused on linkages with, and crowding in, local firms (e.g., [Jude, 2019]) and have found that the effects are not very strong, which is not a full surprise as local firms seem to be often weak in terms of transition to market economy. In the same vein, there have been some positive qualitative and quantitative effects on labour found (cf. [Estrin, 2017]); however, they also depend on national policies and their effects on linkages. These findings confirm the importance of institutions and infrastructure, in close relationship with the quality of policies mentioned above [Kinoshita, Campos, 2003].

\section{An overview of long-term trends}

A first glimpse at the inward and outward FDI flows of the 12 post-Soviet economies over the period 1992-2020 confirms the hypothesis of fluctuations (figure 1), sometimes related to the crises mentioned above, but also related to the lumpiness of FDI. It is to be noted that data may not have been complete and fully reliable in the early period, when data collection was

8 See, for example, [Kalotay, 2004] on the potential of inward FDI in the Russian Federation, [Kalotay, 2010] on the patterns of FDI, and [Kalotay, Sulstarova, 2013] on the prospects of Russian FDI in the Baltic Sea region context. 
in an initial stage. On the contrary, by 2020 major improvements had been registered in almost all countries. In the latest data collection, UNCTAD Secretariat needed to estimate only the flows of Turkmenistan, and could use national reports for the rest of the countries. To be noted that inflows and outflows often seemed to move together, which has been related in part to the phenomenon of round tripping, inflating the FDI flows in some countries, es- pecially the Russian Federation. This phenomenon has been analysed for more than two decades (e.g., [Bulatov, 1998; Pelto et al., 2004; Zavyalova et al., 2019]). It has been concluded that, other than distorting FDI statistics, these flows bring about certain risks on case of crisis in the economies used for round tripping [Kalotay, (2) 2013] and have negative implications for development and governance [Ledyaeva et al., 2013].

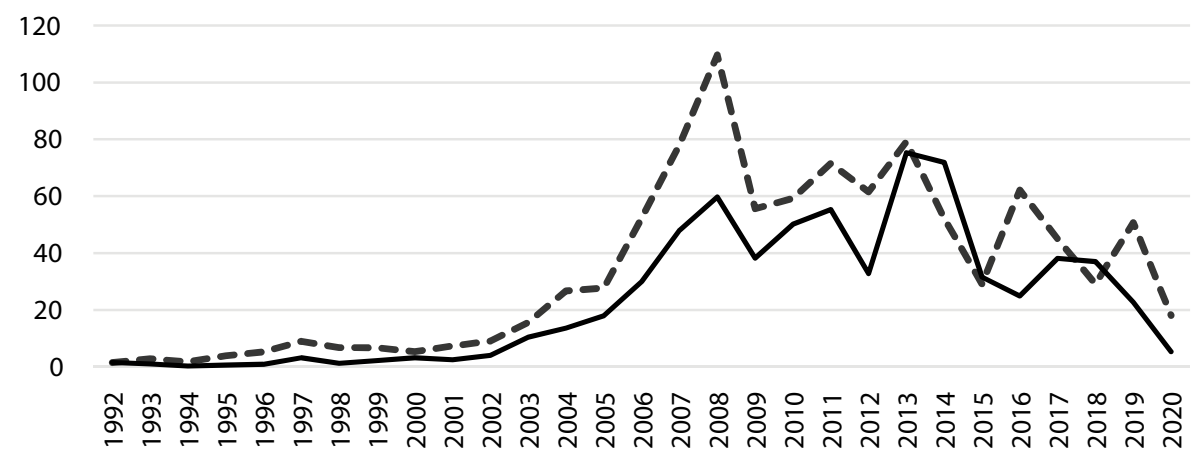

- - - Inflows Outflows

Figure 1. FDI inflows and outflows of the 12 post-Soviet economies, 1992-2020 (Billions of dollars)

Рис. 1. Импорт и экспорт ПИИ 12 постсоветских стран в 1992-2020 гг. (млрд долл.)

Source: The authors' calculations, based on data from the UNCTAD FDI/MNE database.

Having kept reservations about the quality of FDI data in mind, trends by the reported indicate the existence of two periods in flows, a usually upward trend in inflows till the Global Financial Crisis and a downward slide afterwards. Inflows recorded their highest level in 2008 (\$110 billion). Outflows had yet another peak in 2013 ( $\$ 75$ billion), right before the second Russian financial/currency crisis of 20142016, which also brought about a change in the international political context for Russian outward FDI, closely linked with State ownership and influence [Panibratov, 2016; Panibratov et al., 2015]. This latter was related not only to economic events but also a deteriorating international political environment for Russian multinationals, which traditionally account for the bulk of outflows from the group.

FDI stocks provide a more stable indication of main patterns in the long term. They continue accumulating even if flows slow down in a given year. They also allow to derive comparisons with the rest of the world. Indeed, one large drop in stocks was registered in 2008 (both inward and outward), and then in 2014-2015, years when valuations for assets were falling (figure 2). 
In terms of the share of the 12 post-Soviet economies in global inward and outward FDI stocks, the values remained rather low during the whole period of observation, confirming that overall, the economic development strategies of the group were not based heavily on FDI promotion, and also the fact that the group has not become a special magnet for global FDI, despite its advantages in terms of natural resources and markets (the latter is true rather to the large economies of Kazakhstan, the Russian Federation and Ukraine). The share of the region's inward FDI stock in world total reached a maximum of 3.5 per cent in 2010, declining for most of the time in the subsequent period. The share of the region's outward FDI stock in world total reached a maximum of 2 per cent in 2007 before the Global Financial Crisis. As for the measurement of resilience to the latest COVID-19-related crisis, the tendency towards the decline was accentuated in 2020, confirming the vulnerability of FDI in the group.

The patterns above are determined by FDI in a handful of large economies, dominating both inward and outward FDI stocks. According to data for 2020, for economies (the Russian Federation, Kazakhstan, Ukraine and Azerbaijan) accounted for 92 per cent of the inward

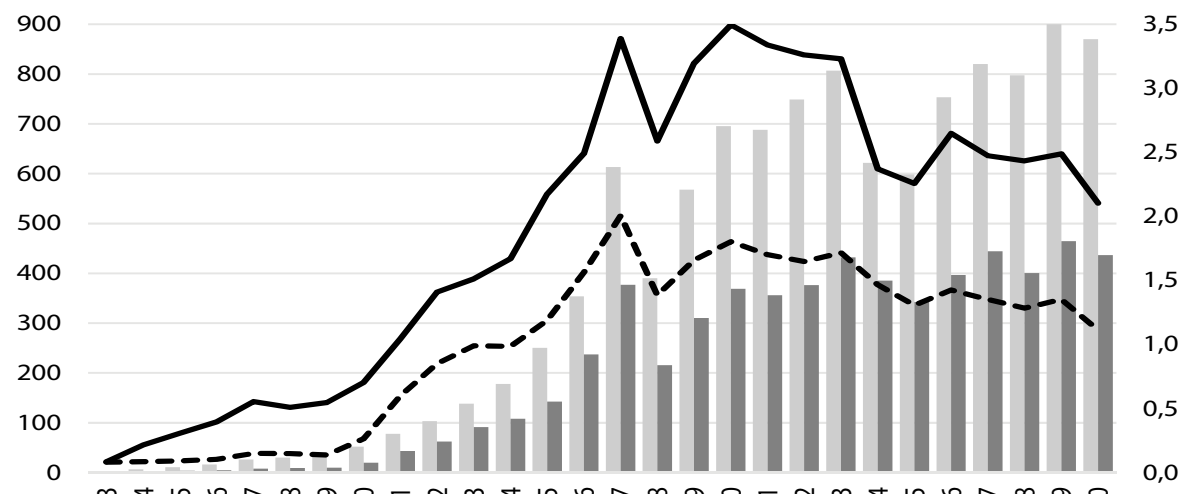

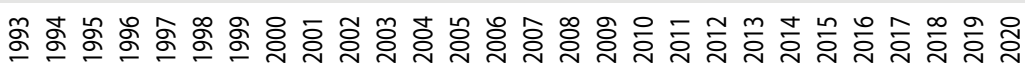

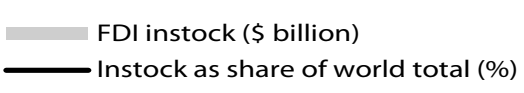

FDI outstock (\$ billion)

- - Outstock as share of world total (\%)

Figure 2. FDI inward stock and outward stock of the 12 post-Soviet economies, 1993-2020 (Billions of dollars and percent share of the world total)

Рис. 2. Накопленные объемы импортированных и экспортированных ПИИ 12 постсоветских стран в 1993-2020 гг. (млрд долл. и \% от общемировых объемов)

Source: The authors' calculations, based on data from the UNCTAD FDI/MNE database.

stock of the group, with the Russian Federation representing 60 per cent (figure 3 ). In outward FDI stocks, the degree of concentration is even higher. The top three economies represent 98 per cent, and the Russian Federation alone 88 per cent (figure 3).
One characteristic that draws apart two post-Soviet economies from the rest of transition economies - Azerbaijan and the Russian Federation - is an unusually high level of outward FDI compared with inward FDI (figure 4), challenging the theory of an investment-development path (see 
(a) Inward FDI stock

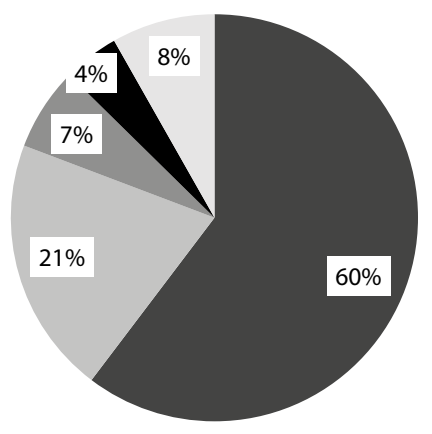

- Russian Federation $₫$ Kazakhstan

- Ukraine

- Azerbaijan

Others (b) Outward FDI stock

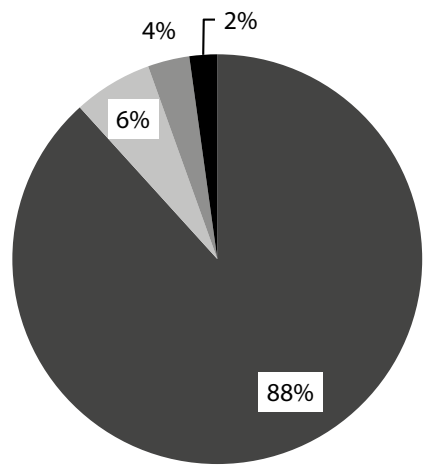

- Russian Federation $\square$ Azerbaijan

Kazakhstan $\quad$ Others

\section{Figure 3. The share of the largest economies in the inward FDI stock and outward FDI stock of the post-Soviet economies, 2020 (Per cent) \\ Рис. 3. Доля крупнейших стран в накопленных объемах импортированных и экспортированных ПИИ на постсоветском пространстве в конце 2020 г. (\%) \\ Source: The authors' calculations, based on data from the UNCTAD FDI/MNE database.}

[Dunning, 1981; Dunning, 1986] in the literature survey). These values - over 80 per cent measures by FDI stocks - are more than twice as high as the values registered in the Visegrad countries (Czechia, Hungary and especially Poland) or in the Baltic States, which are considered to be more advanced in terms of transition to the market economy ${ }^{9}$. In the rest of the post-Soviet group, the ratios are more in line with the IDP, with Kazakhstan for example having a value of 9 per cent.

\section{Basic geographical and sectoral features}

The structural characteristics (geographical and sectoral) are better measured by greenfield commitment data than FDI data because the latter often contain elements of transhipment [Kalotay, 2012] which the efforts towards identifying the ultimate investors can filter out with only limited success. While there is a way to provide estimates with a probabilistic approach for overall flows [Casella, 2019], these are not real data to be used for detecting structural characteristics in overall FDI series. Alternatively, cross-border merger and acquisition (M\&A) data could be used. In certain segments of FDI flows, like the foreign expansion of Russian MNEs before 2014, this mode of entry played an important role [Kalotay, 2015]. However, with the cooling off of international relations, their role diminished drastically (cf. [UNCTAD, 2021]). Hence, a comprehensive view until recent times is better based on greenfield data. To be noted also that conceptually it would be very interesting to include brownfield data, too

\footnotetext{
9 Bennett V. (2016). EBRD Updates Transition Concept. The European Bank for Reconstruction and Development, November 2, 2016. Available at: https://www.ebrd.com/news/2016/ebrd-updates-transition-concept-.html, accessed 15.09.2021.
} 


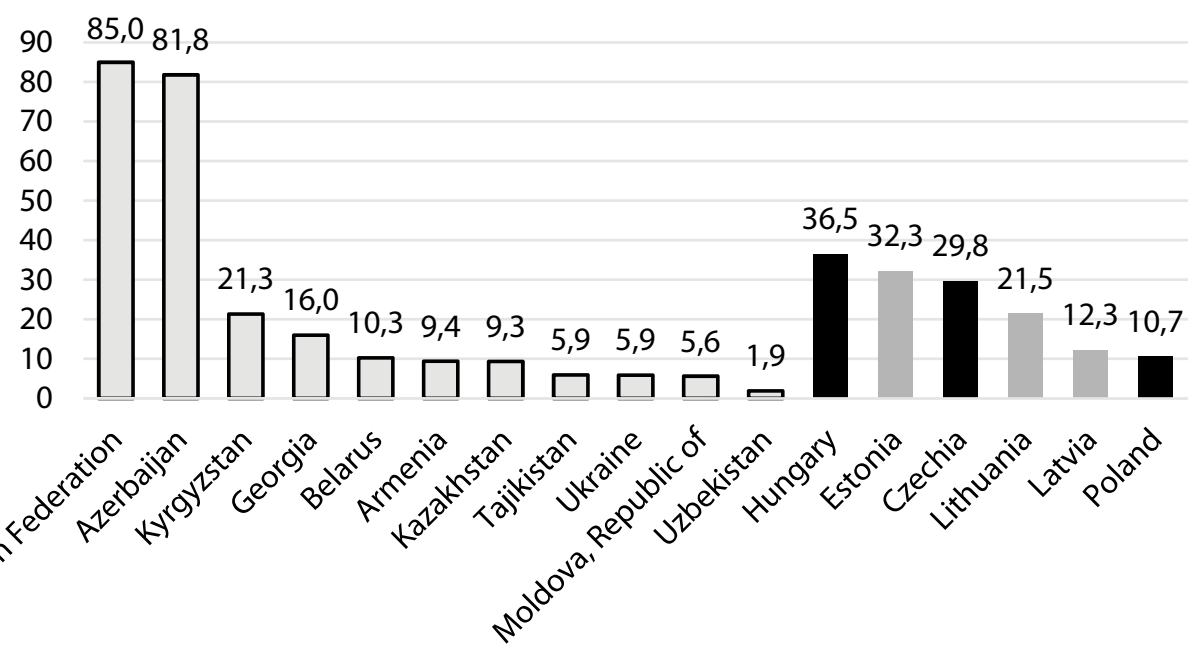

Figure 4. The ratio of FDI outward FDI stock versus inward FDI stock in selected transition economies, 2020 (Per cent)

Рис. 4. Отношение накопленных объемов экспортированных ПИИ к накопленным объемам импортированных ПИИ в ряде стран с переходной экономикой в конце 2020 г. (\%)

Source: The authors' calculations, based on data from the UNCTAD FDI/MNE database.

(cf. [Kalotay, 2001; Estrin, Meyer, 2011]). However, such collections are not available. These transactions are either recorder in M\&A data (at the moment of initial investment) or greenfield numbers (at the moment of additional investment).

Therefore, this article relies on greenfield values, even if they include values of unrealized commitments, showing some flows larger than reality, and even if data are available from 2003 on. We know that 94 per cent of the inflows of the post-Soviet economies have been realized after 2003 and 88 per cent of the inward FDI stock. Another advantage of those greenfield data is their relatively quick availability.

In the inward FDI commitments registered in the 12 post-Soviet economies between 2003 and June 2021, manufacturing accounted for slightly more than half of the total values, related typically to motor vehicles production, coke and refined petroleum and food and beverages, confirming the importance of market seeking motives in the majority of cases (figure 5) ${ }^{10}$. Mining and quarrying, including oil and gas accounts for 14 per cent. The rest was attributed to services, especially transportation and storage.

In terms of source countries, despite efforts for diversification towards developing and transition economies after the political events of 2014 in the Russian Federation and other EAEU member countries, more than two-thirds of the values were originated in developed countries (figure 6). These countries have remained important sources of technology and modern production capacities, not easily replaceable by other countries. The EU accounted

10 In the automotive industry, in some countries, especially in the Republic of Moldova, efficiency-seeking production for global value chains could also be detected. 


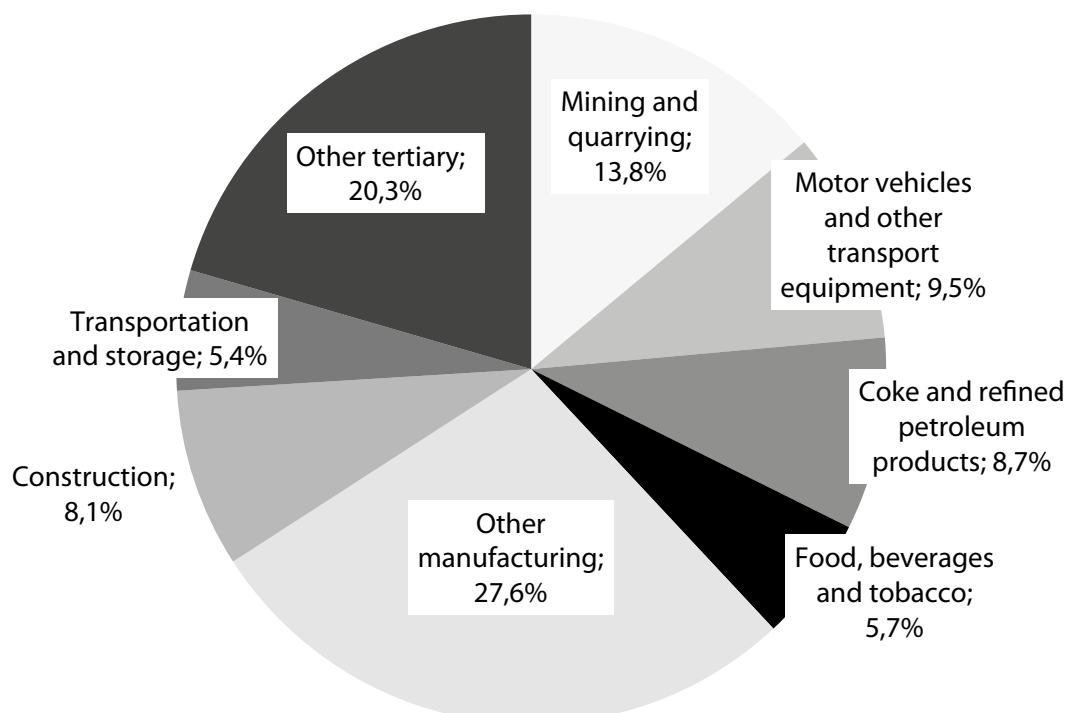

Figure 5. Main industries of inward greenfield FDI commitments in the 12 post-Soviet economies, 2003-June 2021 (Per cent)

Рис. 5. Отраслевая структура импортированных ПИИ в проекты «с нуля» в 12 постсоветских странах в 2003 г. - июне 2021 г. (\%)

Source: The authors' calculations, based on information from the Financial Times Ltd. fDI Markets.

for close to 40 per cent of the greenfield commitments in the 12 post-Soviet economies, with Germany, France and Finland taking the leading roles. With 14 per cent, the United States was the largest single source country. Developing countries represented 23 per cent, of which China alone accounted for 10 per cent. The share of intra-regional projects was 9 per cent. The Russian Federation (7 per cent) was a major investor in most of the other post-Soviet countries.

The sectoral composition of outward greenfield FDI commitments by multinationals from the post-Soviet economies, in their majority Russian multinationals, reflects the strategies of controlling downstream activities in the natural resources in which they specialize. This situation (the concentration of extractive activities at home) results in a relatively low share of mining activities: less than 8 per cent (figure 7 ). In turn, downstream coke and re- fined petroleum and metallurgy together represent close to 30 per cent of the value of commitments. Beside them only automotive is relatively large in manufacturing. In services again, energy (electricity, gas, steam and air conditioning supply) is the largest industry (21 per cent), reflecting the competitive advantages of post-Soviet multinationals, followed by transportation and storage (14 per cent) (figure 7).

The geography of outward FDI greenfield commitments shows a relatively low concentration in developed economies and a high concentration in developing and transition economies, some of which with difficult business environments (e.g., Iraq). This strategy is different from the strategy of cross-border acquisitions of post-Soviet, especially Russian, multinationals, focusing more until recently on ensuring control over assets in developed economies [Kalotay, Panibratov, 2013; Kalotay, 2015]. Developed economies account for 


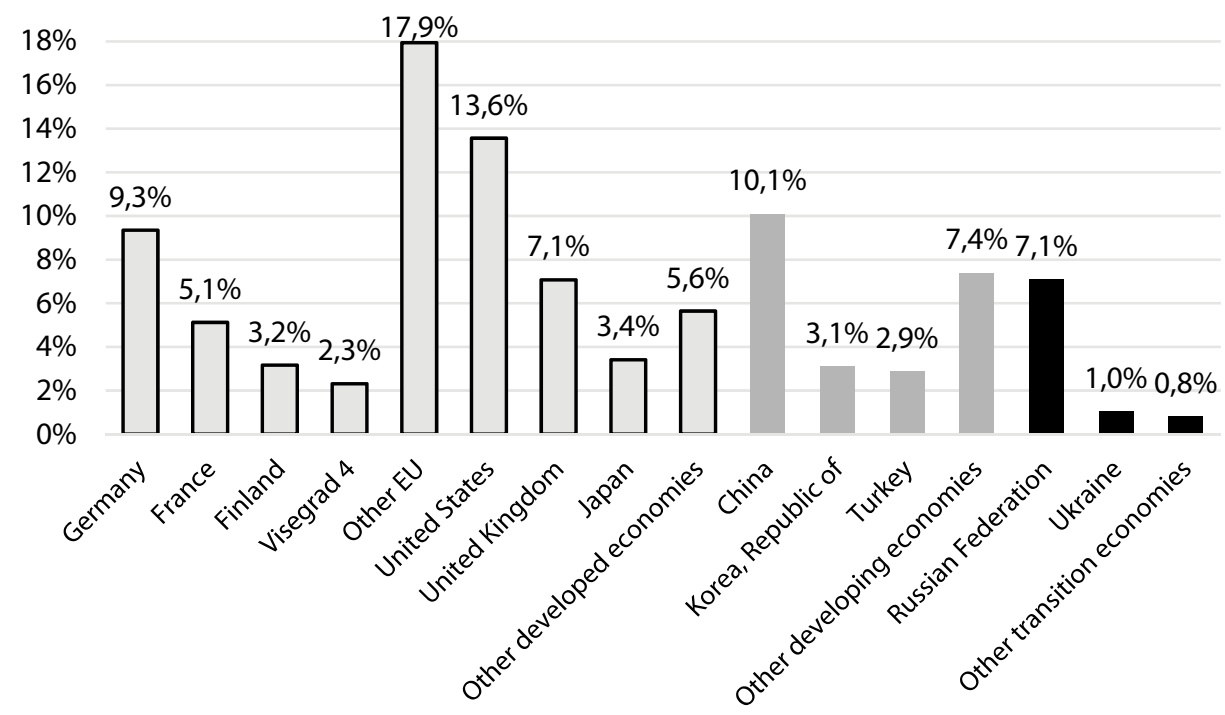

Figure 6. Main source countries of inward greenfield FDI commitments

in the 12 post-Soviet economies, 2003-June 2021 (Per cent)

Рис. 6. Основные страны - источники поступлений ПИИ в проекты «с нуля» в 12 постсоветских странах в 2003 г. - июне 2021 г. (\%)

Source: The authors' calculations, based on information from the Financial Times Ltd. fDI Markets.

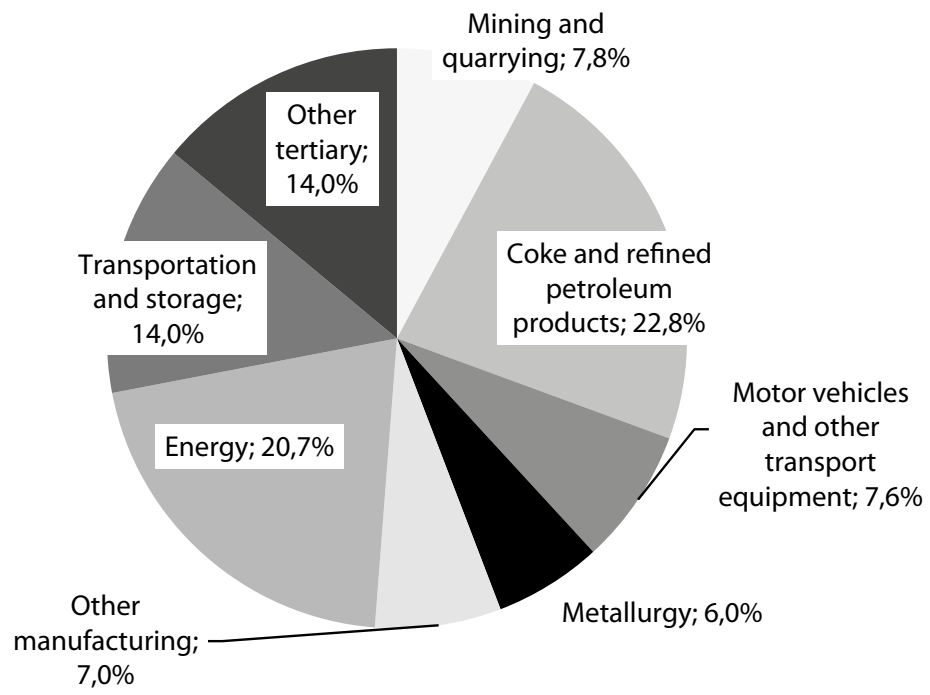

Figure 7. Main industries of outward greenfield FDI commitments from the 12 post-Soviet economies, 2003-June 2021(Per cent)

Рис. 7. Отраслевая структура экспортированных ПИИ в проекты «с нуля» из 12 постсоветских стран в 2003 г. - июне 2021 г. (\%)

Source: The authors' calculations, based on information from the Financial Times Ltd. fDI Markets. 
less than one fifth (figure 8), with Germany being by far the most important target (around 6 per cent). Developing economies account for more than half, with the share of Turkey and Egypt exceeding 10 per cent. Post-Soviet greenfield commitments are well present in all developing regions, Asia alone taking up 37 per cent, Africa 14 per cent and Latin America and the Caribbean 4 per cent. Transition economies also take up roughly one-quarter of greenfield commitments, with Uzbekistan, Kazakhstan and Ukraine, in that order, being the most frequently target economies (figure 8).

\section{Measuring reliance on FDI with the UNCTAD Performance Index}

To draw basis conclusions on the role of FDI in the development strategies of the 12 post-Soviet countries, it is necessary to measure to what degree has the develop- ment of these countries relied on attracting inward FDI and/or promoting outward FDI or both, especially in comparison with other transition economies and groups. To answer that question, we use a modified and further developed version of UNCTAD's classical Performance Index [UNCTAD, 2002, pp. 23-28], which measures the FDI intensity of individual economies or groups. Its formula is the following:

FDI Performance Index $\mathrm{i}=\frac{\mathrm{FDI}_{\mathrm{i}} / \mathrm{FDI}_{\mathrm{V}}}{\mathrm{GDP}_{\mathrm{i}} / \mathrm{GDP}_{\mathrm{V}}}$

Where

- FDI Performance Index $x_{i}$ is the index value for country $\mathrm{i}$

- $\mathrm{FDI}_{\mathrm{i}}$ is the FDI flow or stock of country $i$ in the given period

- $\mathrm{FDI}_{\mathrm{v}}$ is world FDI flow or stock in the given period

- $\mathrm{GDP}_{\mathrm{i}}$ is the GDP for country $\mathrm{i}$ in the given period

- $\mathrm{GDP}_{\mathrm{v}}$ is world GDP in the given period.

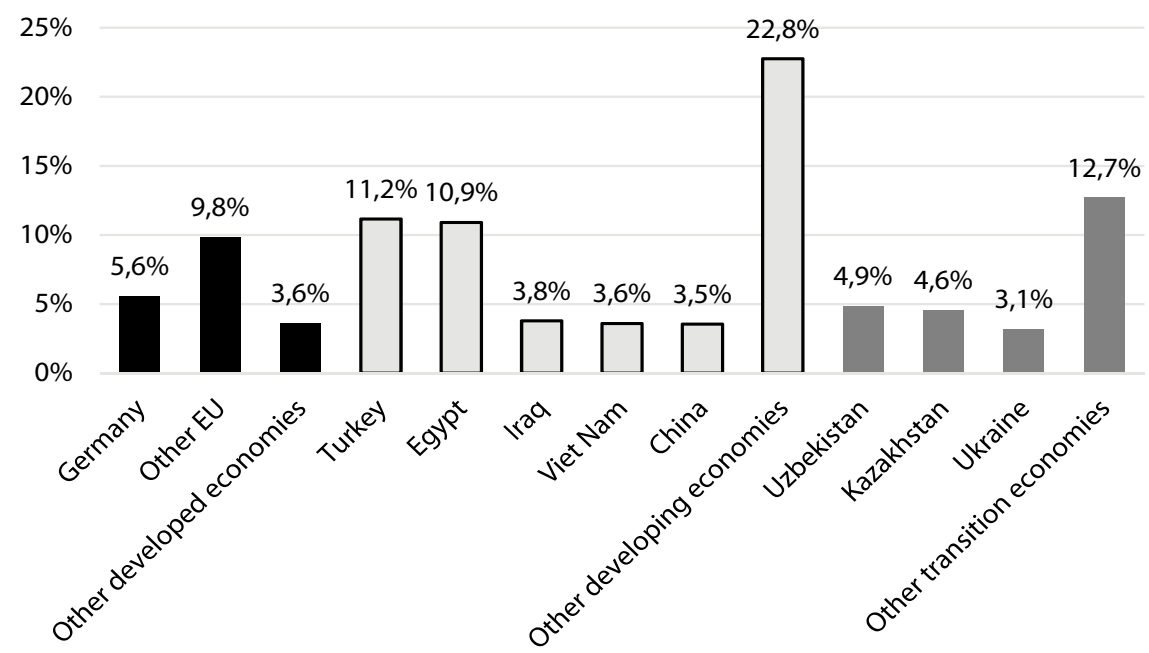

Figure 8. Main target countries of outward greenfield FDI commitments from the 12 postSoviet economies, 2003-June 2021 (Per cent)

Рис. 8. Основные страны - получатели ПИИ из 12 постсоветских стран в проекты «С нуля» В 2003 г. - июне 2021 г. (\%)

Source: The authors' calculations, based on information from the Financial Times Ltd. fDI Markets. 
The Index was originally developed to measure the performance of inflows over three-year averages (to mitigate the effects of cycles and lumpiness). It was explained as follows: "The Inward FDI Performance Index is the ratio of a country's share in global FDI flows to its share in global GDP. Countries with an index value of one receive FDI exactly in line with their relative economic size. Countries with an index value greater than one attract more FDI than may be expected on the basis of relative GDP" [idem, p. 23].

In this article, we have replaced FDI inflows by inward FDI stocks, in order to further minimize the above-mentioned relative weakness of the index, namely its fragility vis-à-vis the volatility and lumpiness of FDI flows. We have added the same measure for outward FDI stocks, and a combination of the two, in order to gauge also the role of outward FDI in economic development strategies. To add a more dynamic perspective, we have measured changes in the index between 2008 and 2020.

The results show that, unlike the other transition groups (the non-EU member Western Balkans, the Baltic States and the new EU members except Baltics), the majority of post-Soviet countries have relied on inward FDI in their development strategies less than the world average both before the Global Financial Crisis and in 2020. The group average increased slightly but remained under 1 (figure 9). However, reflecting the diversity of the group, the ratio of various countries exceeded 1 (for more details, see annex table 1). The group average remained low because of the low values of some large countries, especially Belarus, the Russian Federation, Uzbekistan (in both dates) and Ukraine (in 2020). However, with the exception of Armenia, the Republic of Moldova, Tajikistan and Ukraine, the ratio of inward FDI reliance was increasing in the post-Soviet group. To be noted that in the control groups of the
Baltic States and the other new EU member countries, the ratio, though well beyond 1, was on a downward trend. In some key countries like Lithuania, Poland and Romania, the ratio fell below 1 , indicating a switch to lower than the world average reliance on inward FDI by 2020.

Reliance on outward FDI has remained under the world average in practically all transition economies, post-Soviet and other, and in both periods of time. Only the value for Estonia in 2008 and for Azerbaijan in 2020 exceeded 1. In the Russian Federation, often regarded as a strong outward investing emerging economy, the ratio increased slightly, from 0.48 to 0.55 , but remained far below the benchmark of 1 . As a result, if we measure the combined effects of inward AND outward FDI, all group ratios remained under 1 all the time, indicating that ALL transition economies were still at a low ebb of overall globalization. Of the six economies exceeding the benchmark of 1 in 2020, three were post-Soviet (Azerbaijan, Georgia and Kazakhstan), one a Baltic State (Estonia), one new EU member (Czechia) and one from the Western Balkans (Montenegro). In turn, the bottom five (Uzbekistan, Belarus, Ukraine, Tajikistan and the Republic of Moldova, in that order) were all from the post-Soviet space.

The authors of this article have also tested if it was possible to differentiate the patterns of reliance on FDI by the international policy orientation of post-Soviet countries. The indexes of EAEU members supposed to be more oriented towards intra-regional cooperation - and GUAM members - supposed to be following more opening towards cooperation with Western partners - showed some, but not large differences. The inward FDI Performance Index of the GUAM was slightly higher roughly 1 in both points of time - than in the EAEU group, whose inward index remained below 1 but was rising. As for the outward index, it was well below 1 in both 
groups but higher in the EAEU. As a result, the combined index values converged almost totally by 2020 ( 0.65 for the GUAM group and 0.67 in the EAEU). From this, it can be concluded that the two groups have followed slightly different FDI strategies, with GUAM relying more on inward and the EAEU, which includes the region's dominant capital exporter, the Russian Federation, has relied more on outward FDI.

\section{Concluding findings}

Three decades ago, a world based on almost full State ownership of production and limited relations with other countries (channelled mostly through State trading companies) collapsed in the aftermath of the dissolution of the Soviet Union. In this apparently very stable and immovable context, FDI used to play a very marginal role. Foreign firms could at best form joint ventures with Soviet State-owned firms under the special permission of the central authorities, or engage in non-equity transactions, again under special authorization. As for the "red multinationals" [Hamilton, 1986], they were engaged mostly in trading activities.

In principle, the dissolution of the Soviet Union and transition to market economy opened the doors both inward and outward FDI wide open. However, the variety (or varieties) of capitalism that emerged in the post-Soviet space did not favour either massive or high-quality inflows and limited outflows to activities of value chain control in outward FDI. Both the business environment and the emerging monopolies of local elites (oligarchs) over resources

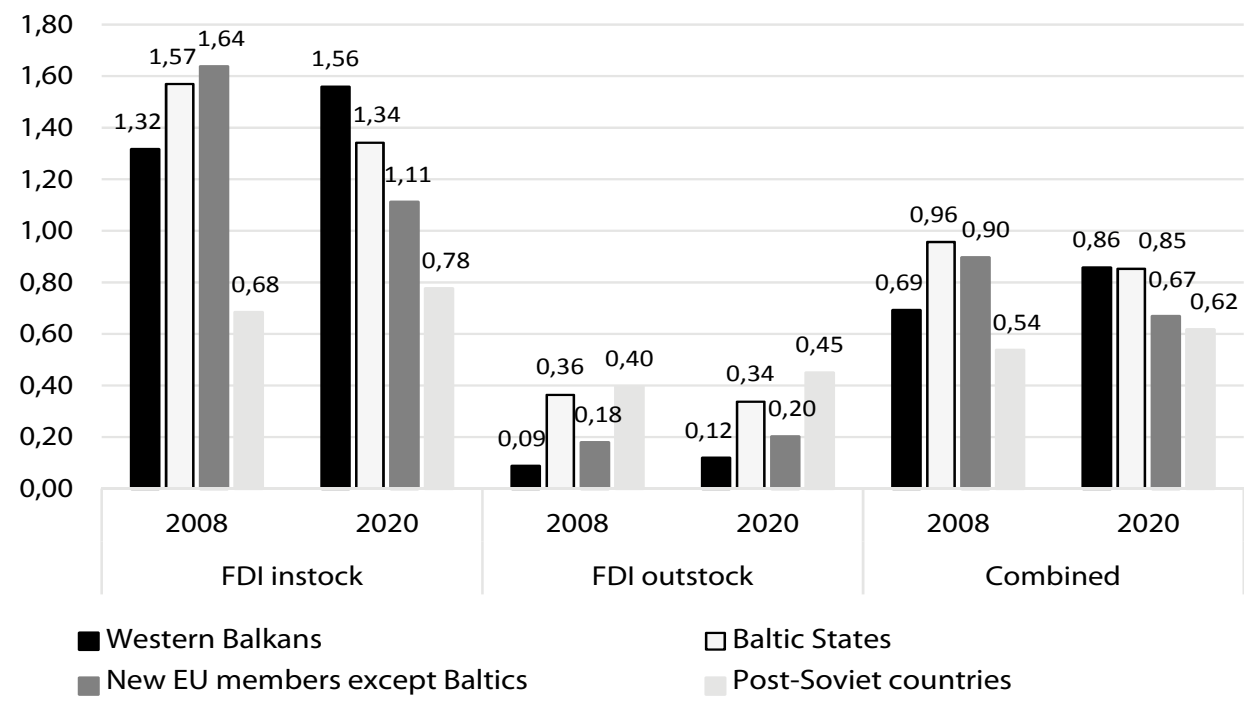

\section{Figure 9. The FDI inward FDI stock, outward FDI stock and combined FDI Performance Indexes of transition economies, group averages, 2008 and 2020 (Ratios) \\ Рис. 9. Накопленные объемы импортированных и экспортированных ПИИ, а также комбинированный показатель привлекательности для ПИИ стран с переходной экономикой, по основным группам в 2008 и 2020 гг.}

Source: The authors' calculations, based on UNCTAD data. 
limited the scope for inward FDI for a long time. In outward FDI, oligarch-based activities have dominated. In most countries, these oligarchs became related to State power. In the largest country, the Russian Federation, this process became patent under the presidency of Vladimir Putin after 1999.

As a results of these development trajectories, the post-Soviet economies have relied relatively little on either inward or outward FDI in their development strategies of the past three decades, though there has been some rise in that reliance over time. This strategy has been different from the strategy of other transition economies, especially the ones that joined the EU in 2000s, which relied heavily on inward FDI in the initial stages of transition, although that dependence diminished over time. It was also different from the strategy of the countries in the Western Balkans, whose reliance was increasing over time. These findings are also in slight variance with the point of view of the investment development path according to which at least the Russian Federation would be in the stage of increasing outward FDI. This is related to the fact that the OFDI/IFDI ratio is high mostly because the ratio of FDI to the relative size of the economy (GDP) is low.

It is particularly challenging to link the fact of low reliance on FDI with GDP growth. The first phase of transition (till 1999) saw a major decline in the group's share in world GDP (from around 2.5 to 1 per cent), but then there was a rise in the same share till 2014 (3.9 per cent) and then again a continuous decline till 2020 (2.4 per cent). It is no easy to find a causality between FDI and GDP and to determine its direction. The group had at least one period of fast growth (2000-2014) without strong reliance on FDI (but still with a major rise in outward FDI). It may also be that the quality of FDI has also mattered, not just its volume.

It is also important to consider the idiosyncratic characteristics of the post-Soviet space when evaluating the role of FDI inflows and outflows and their impact on economic development. In other words, the main benchmark for evaluation would be a hypothetical post-Soviet group that would have performed better in terms of human and economic development. Can we attribute the modest results of development to the political vicissitudes and crises of the post-Soviet countries? Or the post-2014 sanctions and counter-sanctions? (But then how to explain the pre2014 trajectory?) We do not know either if in a hypothetical more prosperous group, inward and outward FDI would have really played a more pronounced role.

Having considered the idiosyncrasies, one observation is still valid: post-Soviet countries in general have not been champions of industrial policies, at least not at the same scale as the efforts of the Asian champions such as China, the Republic of Korea or Singapore, to mention a few, or at least Japan or the European Union ${ }^{11}$. And this is an important consideration because inward and outward FDI promotion is an integral part of industrial policy [UNCTAD, 2018]. Not having strong industrial policies is a missed opportunity, even if one thinks that the domestic and international political environment has not been always favourable. In other words, when we look at the development path of the post-Soviet economies, development denotes mostly an evolution of the economic environment with very modest government guidance and relatively limited actions based on long-term visions of public authorities. FDI flows are part of this picture, and should be evaluated as such.

11 Paradoxically, industrial policies were revived in the Russian Federation after 2014, under the effects of international sanctions, when import substitution became an imperative. Still, these policies integrated the FDI element very little. 


\section{Looking into the future and policy recommendations}

It is not straightforward to draw conclusions for the future of FDI in the group and its role in prospective economic development, especially when taking into consideration the game changing nature of the COVID-19 crisis. COVID-19 itself has not been the focus of this article looking at long-term patterns. However, COVID-19 is relevant in the sense that it was only accelerating pre-existing problems that started well before 2020 (see [UNCTAD, 2020]). Already before the onset of that crisis, both FDI and GDP growth of the post-Soviet economies were on a downward trend, very probably related to the three mega-trends that received a further boost by COVID-19: the challenges of digitalization, sustainable development and the preservation of multilateralism.

In all three areas, the post-Soviet economies were mostly negatively affected by changes in the world economy. In their post-crisis strategies, they will have to adapt faster to the requirements of the new normal, which in principle can be done both through heavy reliance on FDI or not. Some economies of the group have at least some domestic capacities to rely on while waiting for the end of the waitand-see attitude of international investors and have drawn up plans to leave the crisis. However, given the extent of the challenges, it is difficult to envisage a successful exit from the crisis without some form of international engagement in the medium and longer term. That in turn would redefine the role of FDI, which may need to be more adapted to digitalization and more sustainable, even if in the short term that would mean less FDI. In addition, policies towards reinforcing multilateralism need to be revitalized in a world that for some time has been going to the opposite direction for some time. In this later area, the role of the Russian Federa- tion is very different from that of the other post-Soviet States. Even the larger ones such as Kazakhstan and Ukraine are takers of the changing international environment, while the Russian Federation is one of the shapers of the global scene, with all the responsibilities that such a status entails [McCarthy et al., 2019].

Hypotheses about the shape of the post-COVID new world of FDI in the post-Soviet group could be the subject of various important studies in the future, going beyond the scope of this article. The most important question in this respect would be a re-thinking of public development policies, which of course would also encompass FDI promotion and facilitation. However, should the postSoviet countries wish to revitalize FDI, the main goals should be an increased welfare for the majority of the population, more even distribution of wealth and more respect towards environmental consideration. That leads us to the thorny issue of the quality of the government and of public services. It has been a subject of many studies and the conclusions have almost always been a call for better, cleaner governments.

For the deficiencies and distortions of government services, it is not completely wrong to blame the sudden dissolution of the Soviet Union and the lack of local expertise in public administration (with the notable exception of the Russian Federation) or the resource curse However, three decades after independence, it is not possible to stop there. On the most recent list of transparent governments [Transparency International, 2020], Estonia had 75 points of the possible 100 (one point more than Japan and eight more than the United States), Lithuania 60, Georgia 56, Armenia 49, Belarus 47, Kazakhstan 38 (ex aequo with Brazil), Ukraine 33, Azerbaijan and the Russian Federation 30 (the same number of points as Gabon, Malawi and Mali) and Turkmenistan 19 (12 ${ }^{\text {th }}$ from the 
bottom). And yet, till 1991 all these countries belonged to the same Soviet Union. Naturally, transparency is just one of the many aspects of the quality of government services, but still shows their uneven development over the past decades. It is reasonable to believe that the COVID-19 crisis has further increased the importance of good governance.

\section{References}

Adarov A., Hunya G. (2020). Foreign Investments Hit by COVID-19 Pandemic. FDI in Central, East and Southeast Europe. wiiw FDI Report. no 2020-12, Vienna: Vienna Institute for International Economic Studies - wiiw. Available at: https://wiiw.ac.at/foreign-investmentshit-by-covid-19-pandemic-fdi-in-centraleast-and-southeast-europe-p-5540.html, accessed 16.05.2021.

Andreff W. (2011). Les Firmes Multinationales Russes: Vers la Maturité. Papeles de Europa, vol. 23, pp. 2-20. DOI: 10.5209/ rev_PADE.2011.v23.37926

Andreff W. (2015). Outward Foreign Direct Investment from BRIC Countries: Comparing Strategies of Brazilian, Russian, Indian and Chinese Multinational Companies. The European Journal of Comparative Economics, vol. 12, no 2, pp. 79131. Available at: https://halshs.archivesouvertes.fr/halshs-01342391/document, accessed 16.05.2021.

Andreff W., Andreff M. (2017). Multinational Companies from Transition Economies and Their Outward Foreign Direct Investment. Russian Journal of Economics, vol. 3, no 4, pp. 445-474. DOI: $10.1016 /$ j. ruje.2017.12.008

Balakishi S. (2020). Russian Multinational Firms and Their Investment Activities in Emerging Economies: The South Caucasus. Ph.D. thesis, University of Bristol. Available at: https://research-information. bris.ac.uk/en/studentTheses/russian-mul- tinational-firms-and-their-investment-activities-in-em, accessed 16.05.2021.

Bulatov A.S. (1998). Russian Direct Investment abroad: Main Motivations in the Post-Soviet Period. Transnational Corporations, vol. 7, no 1, pp. 69-82. Available at: https://unctad.org/system/files/official-document/iteiit9v7n1_en.pdf, accessed 16.05.2021.

Bulatov A.S. (2017). Offshore Orientation of Russian Federation FDI. Transnational Corporations, vol. 24, no 2, pp. 7189. DOI: 10.18356/ed298a0d-en

Bulatov A.S., Kuznetsov A.V., Ponomarev A.V., Pertseva S.Y., Tatarinova S.M., Maltseva O.A., Tatulov K.G. (2015). The Russian Model of Capital Exports, Moscow: MGIMO-University (in Russian).

Bulatov A.S., Kvashnin Y.D., Kuznetsov A.V., Pertseva S.Y., Platonova I.N., Rebrey S.M., Senyuk N.Y., Tatulov K.G. (2019). Russia in International Capital Flows in 2018 - early 2019: Analytical Report, Moscow: MGIMO-University (in Russian).

Casella B. (2019). Looking through Conduit FDI in Search of Ultimate Investors - A Probabilistic Approach. Transnational Corporations, vol. 26, no 1, pp. 109146. DOI: $10.18356 / 8 \mathrm{a} 8 \mathrm{~b} 094 \mathrm{c}$-en

Curwin K.D., Mahutga M.C. (2014). Foreign Direct Investment and Economic Growth: New Evidence from Post-Socialist Transition Countries. Social Forces, vol. 92, no 3, pp. 1159-1187. DOI: 10.1093/sf/sot128

Dikova D., Panibratov A., Veselova A. (2019). Investment Motives, Ownership Advantages and Institutional Distance: An Examination of Russian Cross-Border Acquisitions. International Business Review, vol. 28, no 4, pp. 625-637. DOI: 10.1016/j. ibusrev.2018.12.007

Dunning J.H. (1981). Explaining the International Direct Investment Position of Countries: Towards a Dynamic or Developmental Approach. Weltwirtschaftliches Archiv, vol. 117, no 1, pp. 30-64. DOI: 10. 1007/BF02696577 
Dunning J.H. (1986). The Investment Development Cycle Revisited. Weltwirtschaftliches Archiv, vol. 122, no 4, pp. 667-676. DOI: 10.1007/BF02707854

Estrin S. (2017). Foreign Direct Investment and Employment in Transition Economies: Has FDI into Transition Economies Had the Expected Effects? IZA World of Labor. no 330. DOI: 10.15185/ izawol.330

Estrin S., Meyer K.E. (2011). Brownfield Acquisitions: A Reconceptualization and Extension. Management International Review, vol. 51, no 4, article number 483. DOI: $10.1007 / \mathrm{s} 11575-011-0088-\mathrm{x}$

Filippov S. (2008). Russia's Emerging Multinationals: Trends and Issues. UNUMERIT Working Paper Series. no 2008062, Maastricht, Netherlands: United Nations University, Maastricht Economic and Social Research and Training Centre on Innovation and Technology. Available at: https://www.merit.unu.edu/publications/ working-papers/abstract/?id=3541, accessed 16.05.2021.

Filippov S. (2011). Russia's Emerging Multinational Companies Amidst the Global Economic Crisis. UNU-MERIT Working Paper Series. no 2011-003, Maastricht, Netherlands: United Nations University, Maastricht Economic and Social Research and Training Centre on Innovation and Technology. Available at: https:// www.merit.unu.edu/publications/working-papers/abstract/?id=4048, accessed 16.05.2021.

Filippov S. (2012). Emerging Russian Multinational Companies: Managerial and Corporate Challenges. European Journal of International Management, vol. 6, no 3, pp. 323-341. DOI: 10.1504/EJIM. 2012.047027

Hamilton G. (ed.) (1986). Red Multinationals or Red Herrings? The Activities of Enterprises from Socialist Countries in the West, New York: St. Martin's Press.

Hunya G. (2008). Can Internationalization through Inward FDI Be Advan- tageous for Russia? Economic Restructuring and Integration in Eastern Europe: Experiences and Policy Implications (eds. Grinberg R., Havlik P., Havrylyshyn O.), Baden-Baden: Nomos, pp. 453-461. DOI: 10.5771/9783845210049-453

Jude C. (2019). Does FDI Crowd out Domestic Investment in Transition Economies? Economics of Transition and Institutional Change, vol. 27, no 1, pp. 163-200. DOI: $10.1111 /$ ecot.12184

Kalotay K. (2001). The Contribution of Foreign Direct Investment to Transition Revisited. The Journal of World Investment, vol. 2, no 2, pp. 259-276. DOI: $10.1163 / 221190001 \mathrm{X} 00266$

Kalotay K. (2004). Will Foreign Direct Investment Take Off in the Russian Federation? The Journal of World Investment \& Trade, vol. 5, no 1, pp. 119-138. DOI: 10.1163/221190004X00335

Kalotay K. (2010). Patterns of Inward FDI in Economies in Transition. Eastern Journal of European Studies, vol. 1, no 2, pp. 55-76. Available at: http://ejes.uaic.ro/ articles/EJES2010_0102_KAL.pdf, accessed 16.05.2021.

Kalotay K. (2012). Indirect FDI. The Journal of World Investment \& Trade, vol. 13, no 4, pp. 542-555. DOI: $10.1163 /$ 221190012 X649841

Kalotay K. (1) (2013). The 2013 Cyprus Bailout and the Russian Foreign Direct Investment Platform. Baltic Rim Economies - Bimonthly Economic Review, no 3/2013, pp. 58-59. Available at: https:// sites.utu.fi/bre/wp-content/uploads/ sites/227/2019/04/BRE_2013_3.pdf, accessed 16.05.2021.

Kalotay K. (2) (2013). FDI in the Former Soviet Periphery in Six Charts. $A I B$ Insights, vol. 13, no 4, pp. 8-12. DOI: 10. 46697/001c.16942

Kalotay K. (2014). The Crimean Crisis and the Future of Russian Outward Foreign Direct Investment. Baltic Rim Economies - Bimonthly Economic Review, no 4/2014, pp. 24-26. Available at: https:// 
papers.ssrn.com/sol3/papers.cfm?abstract_id=2517313, accessed 16.05.2021.

Kalotay K. (2015). Acquisitions as Engines of Foreign Expansion of Russian Multinationals. Handbook of Emerging Market Multinational Corporations (eds. Demirbag M., Yaprak A.), Cheltenham, Glos. Northampton MA: Edward Elgar, pp. 239259. DOI: $10.4337 / 9781782545019.00021$

Kalotay K., Panibratov A. (2013). Crossborder M\&A and Competitive Advantage of Russian EMNEs. The Competitive Advantage of Emerging Market Multinationals (eds. Williamson P.J., Ramamurti R., Fleury A., Leme Fleury M.T.), Cambridge: Cambridge University Press, pp. 220-238. DOI: $10.1017 / \mathrm{CBO} 9781139506694.018$

Kalotay K., Sulstarova A. (2010). Modelling Russian Outward FDI. Journal of International Management, vol. 16, no 2, pp. 131-142. DOI: 10.1016/j.intman.2010. 03.004

Kalotay K., Sulstarova A. (2013). Long-Term Prospects of Inward Foreign Direct Investment in the Baltic Sea Region. Journal of East-West Business, vol. 19, no 12,pp. 79-90. DOI: 10.1080/10669868.2013. 780500

Kinoshita Y., Campos N.F. (2003). Why Does FDI Go Where it Goes? New Evidence from the Transition Economies. IMF Working Paper. no 03/228. Available at: https://www.imf.org/en/Publications/WP/Issues/2016/12/30/Why-DoesFdi-Go-Where-it-Goes-New-EvidenceFrom-the-Transition-Economies-16954, accessed 16.05.2021.

Kononov O. (2010). Ukraine's Inward FDI and Its Policy Context. Columbia FDI Profiles, April 13, 2010. DOI: 10.7916/ D8VM4K3W

Kuznetsov A.V. (2007). Internationalization of the Russian Economy: An Investment Aspect, Moscow: KomKniga (in Russian).

Kuznetsov A.V. (2009). Finland Center for the Study of Investment Relations of Russia. World Economy and In- ternational Relations, no 2, pp. 122-127. Available at: https://www.imemo.ru/index.php?page_id $=1248 \&$ file $=$ https: $/ /$ www.imemo.ru/files/File/magazines/meimo/02_2009/17-Kuznetsov.pdf, accessed 16.05.2021 (in Russian).

Kuznetsov A. (1) (2010). Inward FDI in Russia and Its Policy Context. Columbia FDI Profiles, June 30, 2011. DOI: 10.7916/ D82232NT

Kuznetsov A.V. (2) (2010). Urgent Tasks for Research on Russian TNCs. Transnational Corporations, vol. 19, no 3, pp. 8195. DOI: $10.18356 / \mathrm{a} 4 \mathrm{~d} 8 \mathrm{cef} 8$-en

Kuznetsov A.V. (ed.) (3) (2010). The Influence of Russian Investment Expansion on the Image of Russia in Europe, Moscow: IMEMO RAN (in Russian).

Kuznetsov A. (2011). Russia: Outward FDI and Its Policy Context, Update 2011. Columbia FDI Profiles, August 2, 2011. Available at: https://ssrn.com/abstract $=2337449$, accessed 16.05.2021.

Kuznetsov A. (2012). Inward FDI in Russia and Its Policy Context. Columbia FDI Profiles, September 4, 2012. DOI: 10. 7916/D82J6M2S

Kuznetsov A.V. (2013). Monitoring of Direct Investments of Belarus, Kazakhstan, Russia and Ukraine in Eurasia. EDB Centre for Integration Studies. Report no 19. Available at: https://eabr.org/upload/iblock/ d7a/report_19_en_preview.pdf, accessed 16.05.2021.

Kuznetsov A.V. (2016). Russian Direct Investment as a Factor of Eurasian Integration. Problems of Economic Transition, vol. 58, no 4, pp. 348-361. DOI: 10.1080/ 10611991.2016.1222802

Kuznetsov A.V. (2020). Foreign Direct Investment. International Encyclopedia of Human Geography (ed. Kobayashi A.), Amsterdam: Elsevier, pp. 219-227. DOI: 10. 1016/B978-0-08-102295-5.10070-8

Kuznetsov A.V. (2021). Direct Investment from Russia Abroad: Changes since 2018. Istoriya, no 21, pp. 9-15. DOI: 10. 18254/S207987840015225-6 
Kuznetsov A., Baronina Y., Volodina M., Gemuyeva K., Kvashnin Y., Lukonin S., Makarova A., Nevskaya A., Frumkin B., Chetverikova A., Shchedrin A. (2017). EAEU and Eurasia: Monitoring and Analysis of Direct Investments. EDB Centre for Integration Studies. Report no 47. Available at: https://russiancouncil.ru/upload/ iblock/7c4/edb-centre_2017_report-47_ fdi-eurasia_eng.pdf, accessed 16.05.2021.

Kuznetsov A.V., Kvashnin Y.D., Gutnik A.V. (2013). Monitoring of Mutual Investments in the CIS. EDB Centre for Integration Studies. Report no 15. Available at: https://www.imemo.ru/files/File/en/publ/ 2013/13015_en.pdf, accessed 16.05.2021.

Kuznetsov A.V., Kvashnin Y.D., Gutnik A.V., Slesareva K.V. (1) (2014). Monitoring of Mutual Investments in the CIS Countries-2014. EDB Centre for Integration Studies. Report no 26. DOI: 10.2139/ ssrn. 2524050

Kuznetsov A.V., Kvashnin Y.D., Lukonin S.A., Chetverikova A.S., Shchedrin A.V. (2) (2014). Monitoring of Direct Investments of Russia, Belarus, Kazakhstan and Ukraine in Eurasia - 2014. EDB Centre for Integration Studies. Report no 28. DOI: $10.2139 /$ ssrn.2554961

Kuznetsov A.V., Kvashnin Y.D., Sidorova E.A., Khavronin S.B. (2012). Monitoring Mutual Investments in the CIS Countries. EDB Centre for Integration Studies. Report no 6. Available at: https://ssrn.com/ abstract $=2832081$, accessed 16.05.2021 (in Russian).

Kuznetsov A.V., Nevskaya A.A. (2017). Geography of FDI from Visegrad Countries in Russia. Bulletin of Geography. Socio-economic Series, no 36, pp. 107-115. DOI: 10.1515/bog-2017-0018

Kvashnin Y.D. (2018). Russian-Ukrainian Investment Ties after the Euromaidan. World Economy and International Relations, vol. 62, no 4, pp. 63-71 (in Russian). DOI: 10.20542/0131-2227-2018-62-4-63-71

Ledyaeva S., Karhunen P., Whalley J. (2013). Offshore Jurisdictions (including
Cyprus), Corruption Money Laundering and Russian Round-trip Investment. National Bureau of Economic Research Working Paper Series. no 19019. Available at: http://www.nber.org/papers/w19019, accessed 16.05.2021.

Liuhto K. (ed.) (2006). Expansion or Exodus? Why Do Russian Corporations Invest Abroad? Binghamton NY: International Business Press. Available at: https://www.routledge.com/Expansionor-Exodus-Why-Do-Russian-Corporations-Invest-Abroad/Liuhto/p/book/ 9780789032867, accessed 16.05.2021.

Liuhto K. (2015). Motivations of Russian Firms to Invest Abroad: How Do Sanctions Affect Russia's Outward Foreign Direct Investment? The Baltic Region, no 4(26), pp. 4-19. DOI: $10.5922 / 2079$ 8555-2015-4-1

Liuhto K., Majuri S. (2014). Outward Foreign Direct Investment from Russia: A Literature Review. Journal of East-West Business, vol. 20, no 4, pp. 198-224. DOI: 10.1080/10669868.2014.967434

Liuhto K., Sutyrin S., Blanchard J.-M.F. (eds.) (2017). The Russian Economy and ForeignDirectInvestment, Abingdon, OxonNew York: Routledge. DOI: 10.4324/ 9781315651101

Liuhto K., Vahtra P. (2007). Foreign Operations of Russia's Largest Industrial Corporations - Building a Typology. Transnational Corporations, vol. 16, no 1, pp. 117-144. Available at: https://digitallibrary.un.org/record/605091? $\ln =\mathrm{en}$, accessed 16.05.2021.

McCarthy D.J., Puffer S.M., Satinsky D.M. (2019). Will Russia Have a Role in the Changing Global Economy? Contrasting Western and Russian Cultural Lenses. Cross Cultural \& Strategic Management, vol. 26, no 2, pp. 265-289. DOI: 10.1108/CCSM-10-2018-0164

Okafor G., Webster A. (2016). Foreign Direct Investment in Transition Economies of Europe and the Former Soviet Union. Palgrave Dictionary of Emerging Markets 
and Transition Economics (eds. Hölscher J., Tomann H.), Houndmills, Basingstoke: Palgrave Macmillan, pp. 413-434. DOI: 10. 1007/978-1-137-37138-6_22

Panibratov A. (2012). Russian Multinationals: From Regional Supremacy to Global Lead, Abingdon, Oxon - New York: Routledge. Available at: https://www.routledge. $\mathrm{com} /$ Russian-Multinationals-From-Regional-Supremacy-to-Global-Lead/Panibratov/p/book/9780415731348, accessed 16.05.2021.

Panibratov A. (2016). Home Government Influence on Russian MNEs: Balancing Control against Interest. International Journal of Emerging Markets, vol. 11, no 4, pp.474-496. DOI: 10.1108/IJoEM-11-20140193

Panibratov A., Ermolaeva A., Abramkov A. (2015). The Liability of Foreignness in the Internationalization Process of Russian Energy Companies. Vestnik of Saint-Petersburg University. Series 8: Management, no 2, pp. 39-73. Available at: https://www.elibrary.ru/download/elibrary_23752444_10565469.pdf, accessed 16.05.2021 (in Russian).

Panibratov A., Kalotay K. (2009). Russian Outward FDI and Its Policy Context. Columbia FDI Profiles, October 13, 2009. DOI: 10.7916/D84173W5

Panibratov A., Michailova S. (2019). The Role of State Ownership and Home Government Political Support in Russian Multinationals' Internationalization. International Journal of Emerging Markets, vol. 14, no 3, pp. 436-450. DOI: 10.1108/ IJOEM-10-2017-0380

Pelto E., Vahtra P., Liuhto K. (2004). Cyp-Rus Investment Flows to Central and Eastern Europe - Russia's Direct and Indirect Investments via Cyprus to CEE. Journal of Business Economics and Management, vol. 5, no 1, pp. 3-13. DOI: 10.1080/ 16111699.2004.9636063

Petrushkevich E.N. (2010). The Structure and Nature of Foreign Direct Investment in the Republic of Belarus. Banking
Bulletin, Information-analytical and Scientific-practical Journal of the National Bank of the Republic of Belarus, no 16(489), pp.20-26.Availableat:http://www.nbrb.by/ bv/arch.asp?id=489, accessed 16.05.2021 (in Russian).

Petrushkevich E.N. (2019). State Regulation of International Flows of Direct Investment in the Republic of Belarus. Belarusian Economic Journal, no 1(86), pp. 6380. Available at: https://elibrary.ru/item. asp?id=37179051, accessed 16.05.2021 (in Russian).

Sauvant K.P. (2006). Inward and Outward FDI and the BRICS. Emerging Economies and the Transformation of International Business: Brazil, Russia, India and China (BRICs) (ed. Subhash C. Jain), Cheltenham, Glos. - Northampton MA: Edward Elgar, pp. 313-409. DOI: 10.4337/ 9781847202987.00024

Shmarlovskaya G.A., Petrushkevich E.N. (2010). Monitoring the Investment Climate and FDI Policy of the Republic of Belarus, Minsk: Misanta (in Russian).

Tepavcevic S. (2015). The Motives for Russian State-owned Companies for Outward Foreign Direct Investment and Its Impact on State-Company Cooperation: Observations Concerning the Energy Sector. Transnational Corporations, vol. 23, no 1, pp. 29-58. DOI: $10.18356 / 2$ cca116 6-en

Transparency International (2020). Corruption Perceptions Index 2020, Berlin: Transparency International. Available at: https://www.transparency.org/en/cpi/ 2020/index/nzl, accessed 16.05.2021.

UNCTAD (2002). World Investment Report 2002: Transnational Corporations and Export Competitiveness, New York and Geneva: United Nations.

UNCTAD (2018). World Investment Report 2018: Investment and New Industrial Policies, New York and Geneva: United Nations.

UNCTAD (2020). World Investment Report 2020: International Production 
beyond the Pandemic, New York and Geneva: United Nations.

UNCTAD (2021). World Investment Report 2021: Investing in Sustainable Recovery, New York and Geneva: United Nations.

UN.ECE (2001). Chapter 5: Economic Growth and Foreign Direct Investment in the Transition Economies. Economic Survey of Europe, no 1, pp. 185-225. Available at: https://digitallibrary.un.org/record/ $443369 ? \ln =e n$, accessed 16.05.2021.

United Nations (1992). World Investment Directory 1992: Central and Eastern Europe, New York: United Nations. Available at: https://digitallibrary.un.org/record/ $158036 ? \ln =$ en, accessed 16.05.2021.

Vahtra P., Liuhto K. (2006). An Overview of Russia's Largest Corporations Abroad. Journal of East-West Business, vol. 11, no 3-4, pp. 23-40. DOI: 10.1300/ J097v11n03_03

Weiner C. (2018). International Expansion of Russian Multinationals: A Focus on
Home-country Push Factors, Europe and Five CEE Countries. Centre for Economic and Regional Studies HAS Institute of World Economics Working Paper. no 250. DOI: $10.13140 /$ RG.2.2.13322.36808

Weiner C. (2020). Russian Multinational Direct Investment in East Central European Countries. Emerging-market Multinational Enterprises in East Central Europe (ed. Szunomár Á.), Cham: Palgrave Macmillan, pp. 153-195. DOI: 10. 1007/978-3-030-55165-0_6

Zabortseva Y.N. (2014). Rethinking the Economic Relationship between Kazakhstan and Russia. Europe-Asia Studies, vol. 66, no 2, pp. 311-327. DOI: 10.1080/ 09668136.2013 .872333

Zavyalova E.B., Tkachev V.N., Berezko V.E., Perepelkin A.N. (2019). Trends and Issues in Economic Relations of $\mathrm{Cy}$ prus and Russia. The Cyprus Review, vol. 31, no 3, pp. 139-157. Available at: http:// cyprusreview.org/index.php/cr/article/ view/672, accessed 16.05.2021. 
Annex table. The inward, outward and combined FDI stock Performance Indexes of individual transition economies, 2008 and 2020 (Ratios)

Приложение. Таблица. Накопленные объемы импортированных и экспортированных ПИИ, а также комбинированный показатель привлекательности для ПИИ по отдельным странам с переходной экономикой в 2008 и 2020 гг.

\begin{tabular}{|c|c|c|c|c|c|c|c|c|c|c|c|}
\hline \multicolumn{4}{|c|}{ Inward } & \multicolumn{4}{|c|}{ Outward } & \multicolumn{4}{|c|}{ Combined } \\
\hline 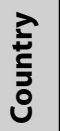 & $\begin{array}{l}\text { 을 } \\
\text { 운 }\end{array}$ & $\stackrel{\infty}{\circ}$ & 옹 & 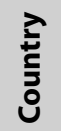 & $\begin{array}{l}\text { 을 } \\
\text { 운 }\end{array}$ & $\stackrel{\infty}{\stackrel{్}{0}}$ & 융 & 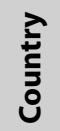 & $\begin{array}{l}\text { 을 } \\
\text { 운 }\end{array}$ & $\stackrel{\infty}{\stackrel{్}{~}}$ & 융 \\
\hline ME & W. Balkan & .. & 2.69 & $A Z$ & Post-Soviet & 0.44 & 1.36 & EE & Baltic & 1.87 & 1.55 \\
\hline GE & Post-Soviet & 2.18 & 2.39 & EE & Baltic & 1.08 & 0.78 & $A Z$ & Post-Soviet & 0.50 & 1.47 \\
\hline $\mathrm{EE}$ & Baltic & 2.69 & 2.28 & RU & Post-Soviet & 0.48 & 0.55 & GE & Post-Soviet & 1.16 & 1.42 \\
\hline KZ & Post-Soviet & 1.87 & 1.89 & HU & New EU & 0.55 & 0.52 & ME & W. Balkan & .. & 1.40 \\
\hline BG & New EU & 3.43 & 1.81 & $\mathrm{CZ}$ & New EU & 0.22 & 0.50 & $\mathrm{CZ}$ & New EU & 1.11 & 1.07 \\
\hline RS & W. Balkan & 1.41 & 1.76 & GE & Post-Soviet & 0.19 & 0.40 & $\mathrm{KZ}$ & Post-Soviet & 0.97 & 1.06 \\
\hline $\mathrm{CZ}$ & New EU & 2.02 & 1.61 & $\mathrm{SI}$ & New EU & 0.62 & 0.35 & BG & New EU & 1.74 & 0.98 \\
\hline$A Z$ & Post-Soviet & 0.57 & 1.58 & KG & Post-Soviet & 0.00 & 0.26 & RS & W. Balkan & 0.76 & 0.98 \\
\hline TM & Post-Soviet & 1.03 & 1.52 & LT & Baltic & 0.18 & 0.20 & HU & New EU & 1.44 & 0.94 \\
\hline $\mathrm{AL}$ & W. Balkan & 0.94 & 1.40 & $\mathrm{KZ}$ & Post-Soviet & 0.10 & 0.19 & $\mathrm{AL}$ & W. Balkan & 0.49 & 0.78 \\
\hline HU & New EU & 2.36 & 1.34 & RS & W. Balkan & 0.12 & 0.16 & KG & Post-Soviet & 0.56 & 0.73 \\
\hline SK & New EU & 2.21 & 1.26 & LV & Baltic & 0.12 & 0.16 & LV & Baltic & 0.72 & 0.72 \\
\hline LV & Baltic & 1.34 & 1.25 & $\mathrm{AL}$ & W. Balkan & 0.05 & 0.11 & SK & New EU & 1.15 & 0.70 \\
\hline MK & W. Balkan & 1.76 & 1.21 & SK & New EU & 0.12 & 0.11 & MK & W. Balkan & 0.89 & 0.63 \\
\hline$H R$ & New EU & 1.70 & 1.18 & BG & New EU & 0.11 & 0.11 & $H R$ & New EU & 1.00 & 0.63 \\
\hline KG & Post-Soviet & 1.14 & 1.17 & PL & New EU & 0.06 & 0.10 & RU & Post-Soviet & 0.51 & 0.59 \\
\hline BA & W. Balkan & 1.35 & 0.99 & AM & Post-Soviet & 0.02 & 0.08 & SI & New EU & 0.77 & 0.58 \\
\hline RO & New EU & 1.28 & 0.89 & $B A$ & W. Balkan & 0.03 & 0.06 & LT & Baltic & 0.67 & 0.54 \\
\hline LT & Baltic & 1.17 & 0.87 & BY & Post-Soviet & 0.00 & 0.05 & $B A$ & W. Balkan & 0.68 & 0.54 \\
\hline PL & New EU & 1.18 & 0.86 & MD & Post-Soviet & 0.04 & 0.05 & PL & New EU & 0.61 & 0.49 \\
\hline MD & Post-Soviet & 1.46 & 0.85 & TJ & Post-Soviet & .. & 0.05 & AM & Post-Soviet & 0.62 & 0.48 \\
\hline AM & Post-Soviet & 1.24 & 0.85 & HR & New EU & 0.32 & 0.05 & RO & New EU & 0.64 & 0.47 \\
\hline TJ & Post-Soviet & 0.89 & 0.79 & ME & W. Balkan & 0.10 & 0.05 & MD & Post-Soviet & 0.74 & 0.46 \\
\hline $\mathrm{SI}$ & New EU & 0.91 & 0.79 & UA & Post-Soviet & 0.15 & 0.04 & TJ & Post-Soviet & & 0.43 \\
\hline UA & Post-Soviet & 1.06 & 0.66 & RO & New EU & 0.03 & 0.02 & UA & Post-Soviet & 0.60 & 0.36 \\
\hline RU & Post-Soviet & 0.54 & 0.62 & MK & W. Balkan & 0.04 & 0.02 & BY & Post-Soviet & 0.22 & 0.29 \\
\hline BY & Post-Soviet & 0.45 & 0.50 & UZ & Post-Soviet & .. & 0.01 & UZ & Post-Soviet & & 0.19 \\
\hline UZ & Post-Soviet & 0.35 & 0.36 & & & & & & & & \\
\hline
\end{tabular}

Source: The authors' calculations, based on UNCTAD data.

Note: Data are not available for the outward FDI stock of Turkmenistan. In other countries, ... denotes non-availability of information. 


\section{Прямые иностранные инвестиции на постсоветском пространстве спустя три десятилетия после распада СССР}

\section{Кальман КАЛОТАЙ}

кандидат экономических наук (Венгерская академия наук), PhD (Университет Корвина, Будапешт, Венгрия);

сотрудник по экономическим вопросам

Конференция ООН по торговле и развитию (ЮНКТАД), Avenue de la Paix 8-14, 1202, Женева, Швейцария (ушел в отставку 1 сентября 2021 года);

почетный профессор

Университет Корвина, Fővám tér 8, 1093, Будапешт, Венгрия

E-mail: kalotayk@gmail.com

ORCID: 0000-0001-7349-9365

\section{Астрит СУЛСТАРОВА}

PhD (Институт последипломного образования, Женева (IHEID), Швейцария); старший сотрудник по экономическим вопросам

Конференция ООН по торговле и развитию (ЮНКТАД), Avenue de la Paix 8-14, 1202, Женева, Швейцария

E-mail: astrit.sulstarova@un.org

ORCID ID: 0000-0002-6972-4942

ЦИТИРОВАНИЕ: Калотай К., Сулстарова А. (2021). Прямые иностранные инвестиции на постсоветском пространстве спустя три десятилетия после распада СССР // Контуры глобальных трансформаций: политика, экономика, право. T. 14. № 5. C. 30-60. DOI: 10.23932/2542-0240-2021-14-5-2

Статья поступила в редакцию 03.08.2021.

АННОТАЦИЯ. Бъвиий Советский Союз распался три десятилетия назад. Знаменательный 1991 2. не только стал началом независимости для стран постсоветского пространства, но и отправной точкой их перехода от иентрализованной плановой экономики к капитализму, пусть и часто с местной спеиификой. На момент написания этой статьи, нацеленной на анализ долгосрочных структурных характеристик притока и оттока прямых иностранных инвестиицй (ПИИ), 12 постсоветских экономик сталкива- ются с новыми проблемами, связанными с COVID-19, отличными от проблем постсочиалистической трансбормаиии. После краткого обзора литературы, в котором освешаются основные вопросы, поднятые академическими исследованиями, в статье анализируются долгосрочные тендениии и основные характеристики (географические и секторальные) ПИИ, с особым упором на объявления о новых проектах с 2003 г. (год начала предоставления данных). В статье также рассматривается, в какой степени экономическое развитие 
основывалось на притоке прямых иностранных инвестииий, на стимулировании их оттока либо на том и другом. Показатели 12 постсоветских экономик сопоставляются с показателями других стран с переходной экономикой, таких, как странь Балтии, Юго-Восточная Европа и/или Вишеградская группа. В статье делается вывод о том, что усилия по использованию притока ПИИ в иелях развития были скромными, даже если в притоках можно наблюдать некоторое сближение с другими странами с переходной экономикой, которые более сознательно использовали ПИИ для своего развития.

КЛЮЧЕВЫЕ СЛОВА: приток ПИИ, вывоз ПИИ, переходный период, постсоветское пространство, экономическое развитие.

\section{Список литературы}

Булатов А.С., Квашнин Ю.Д., Кузнецов А.В., Перцева С.Ю., Платонова И.Н., Ребрей С.М., Сенюк Н.Ю., Татулов К.Г. (2019). Россия в международном движении капитала в 2018 - начале 2019 года: аналитический доклад. М.: МГИМО-Университет // https://mgimo. ru/library/publications/rossiya_v_mezhdunarodnom_dvizhenii_kapitala_v_2018_nachale_2019_goda/, дата обращения 16.05.2021.

Булатов А.С., Кузнецов А.В., Пономарев А.В., Перцева С.Ю., Татаринова С.М., Мальцева О.А., Татулов К.Г. (2015). Российская модель экспорта капитала. М.: МГИМО-Университет // https://mgimo.ru/upload/iblock/c9f/c57c 692fe7ff242a5a2603552eccd61f.pdf, дата обращения 16.05.2021.

Квашнин Ю.Д. (2018). Российскоукраинские инвестиционные связи после Евромайдана // Мировая экономика и международные отношения. Т. 62.
№ 4. C. 63-71. DOI: 10.20542/0131-22272018-62-4-63-71

Кузнецов А.В. (2007). Интернационализация российской экономики: инвестиционный аспект. М.: КомКнига.

Кузнецов А.В. (2009). Финляндский центр изучения инвестиционных связей России // Мировая экономика и международные отношения. № 2. С. 122-127 // https://www.imemo.ru/index.php?page_ id $=1248 \&$ file $=$ https: $/ /$ www.imemo. $\mathrm{ru} /$ files/File/magazines/meimo/02 2009/17-Kuznetsov.pdf, дата обращения 16.05.2021.

Кузнецов А.В. (2010). Влияние российской инвестиционной экспансии на образ России в Европе. М.: ИМЭМО PAH // https://www.imemo.ru/files/File/ ru/publ/2010/10006.pdf, дата обращения 16.05.2021.

Кузнецов А.В., Квашнин Ю.Д., Сидорова Е.А., Хавронин С.Б. (2012). Мониторинг взаимных инвестиций в странах СНГ. СПб.: Центр интеграционных исследований // https://ssrn. com/abstract=2832081, дата обращения 16.05.2021.

Панибратов А.Ю., Ермолаева Л.А., Абрамков А.Е. (2015). «Бремя иностранца» в процессе интернационализации российских энергетических компаний // Вестник Санкт-Петербургского университета. Серия 8: Менеджмент. № 2/2015. C. 39-73 // https://www.elibrary.ru/download/elibrary_23752444_10565469.pdf, дата обращения 16.05.2021.

Петрушкевич Е.Н. (2010). Структура и характер прямых иностранных инвестиций в Республике Беларусь // Банковский вестник. Информационноаналитический и научно-практический журнал Национального банка Республики Беларусь. № 16(489). С. 20-26 // http://www.nbrb.by/bv/arch.asp?id=489, дата обращения 16.05.2021.

Петрушкевич Е.Н. (2019). Государственное регулирование международных потоков прямых инвестиций в Рес- 
публике Беларусь // Белорусский экономический журнал. № 1(86). С. 63-80 // https://elibrary.ru/item.asp?id=37179051, дата обращения 16.05.2021.

Шмарловская Г.А., Петрушкевич Е.Н. (2010). Мониторинг инвестиционного климата и ПИИ-политики Республики Беларусь. Минск: Мисанта // https:// www.elibrary.ru/item.asp?id $=42928046$, дата обращения 16.05.2021.

Adarov A., Hunya G. (2020). Foreign Investments Hit by COVID-19 Pandemic. FDI in Central, East and Southeast Europe // wiiw FDI Report. no 2020-12, Vienna: Vienna Institute for International Economic Studies - wiiw // https://wiiw.ac.at/ foreign-investments-hit-by-covid-19-pandemic-fdi-in-central-east-and-southeasteurope-p-5540.html, дата обращения 16.05.2021.

Andreff W. (2011). Les Firmes Multinationales Russes: Vers la Maturité // Papeles de Europa, vol. 23, pp. 2-20. DOI: 10.5209/rev_PADE.2011.v23.37926

Andreff W. (2015). Outward Foreign Direct Investment from BRIC Countries: Comparing Strategies of Brazilian, Russian, Indian and Chinese Multinational Companies // The European Journal of Comparative Economics, vol. 12, no 2, pp. 79131 // https://halshs.archives-ouvertes.fr/ halshs-01342391/document, дата обращения 16.05.2021.

Andreff W., Andreff M. (2017). Multinational Companies from Transition Economies and Their Outward Foreign Direct Investment // Russian Journal of Economics, vol. 3, no 4, pp. 445-474. DOI: 10.1016/j.ruje.2017.12.008

Balakishi S. (2020). Russian Multinational Firms and Their Investment Activities in Emerging Economies: The South Caucasus. Ph.D. thesis, University of Bristol // https://research-information. bris.ac.uk/en/studentTheses/russian-multinational-firms-and-their-investment-activities-in-em, дата обращения 16.05.2021.
Bulatov A.S. (1998). Russian Direct Investment abroad: Main Motivations in the Post-Soviet Period // Transnational Corporations, vol. 7, no 1, pp. 6982 // https://unctad.org/system/files/official-document/iteiit9v7n1_en.pdf, дата обращения 16.05.2021.

Bulatov A.S. (2017). Offshore Orientation of Russian Federation FDI // Transnational Corporations, vol. 24, no 2, pp. 7189. DOI: $10.18356 /$ ed298a0d-en

Casella B. (2019). Looking through Conduit FDI in Search of Ultimate Investors - A Probabilistic Approach // Transnational Corporations, vol. 26, no 1 , pp. 109-146. DOI: 10.18356/8a8b094c-en

Curwin K.D., Mahutga M.C. (2014). Foreign Direct Investment and Economic Growth: New Evidence from PostSocialist Transition Countries // Social Forces, vol. 92, no 3, pp. 1159-1187. DOI: $10.1093 /$ sf $/$ sot 128

Dikova D., Panibratov A., Veselova A. (2019). Investment Motives, Ownership Advantages and Institutional Distance: An Examination of Russian Cross-Border Acquisitions // International Business Review, vol. 28, no 4, pp. 625-637. DOI: 10.1016/j.ibusrev.2018.12.007

Dunning J.H. (1981). Explaining the International Direct Investment Position of Countries: Towards a Dynamic or Developmental Approach // Weltwirtschaftliches Archiv, vol. 117, no 1, pp. 30-64. DOI: $10.1007 / \mathrm{BF} 02696577$

Dunning J.H. (1986). The Investment Development Cycle Revisited // Weltwirtschaftliches Archiv, vol. 122, no 4, pp. 667-676. DOI: 10.1007/BF02707854

Estrin S. (2017). Foreign Direct Investment and Employment in Transition Economies: Has FDI into Transition Economies Had the Expected Effects? // IZA World of Labor. no 330. DOI: 10.15185/ izawol.330

Estrin S., Meyer K.E. (2011). Brownfield Acquisitions: A Reconceptualization and Extension // Management Interna- 
tional Review, vol. 51, no 4, article number 483. DOI: $10.1007 / s 11575-011-0088-x$

Filippov S. (2008). Russia’s Emerging Multinationals: Trends and Issues // UNU-MERIT Working Paper Series. no 2008-062, Maastricht, Netherlands: United Nations University, Maastricht Economic and Social Research and Training Centre on Innovation and Technology // https://www.merit.unu.edu/publications/working-papers/abstract/?id=3541, дата обращения 16.05.2021.

Filippov S. (2011). Russia’s Emerging Multinational Companies Amidst the Global Economic Crisis // UNU-MERIT Working Paper Series. no 2011-003, Maastricht, Netherlands: United Nations University, Maastricht Economic and Social Research and Training Centre on Innovation and Technology // https://www.merit.unu.edu/publications/working-papers/ abstract/?id=4048, дата обращения 16.05.2021.

Filippov S. (2012). Emerging Russian Multinational Companies: Managerial and Corporate Challenges // European Journal of International Management, vol. 6, no 3, pp. 323-341. DOI: 10.1504/EJIM. 2012.047027

Hamilton G. (ed.) (1986). Red Multinationals or Red Herrings? The Activities of Enterprises from Socialist Countries in the West, New York: St. Martin's Press.

Hunya G. (2008). Can Internationalization through Inward FDI Be Advantageous for Russia? // Economic Restructuring and Integration in Eastern Europe: Experiences and Policy Implications (eds. Grinberg R., Havlik P., Havrylyshyn O.), Baden-Baden: Nomos, pp. 453-461. DOI: 10.5771/9783845210049-453

Jude C. (2019). Does FDI Crowd out Domestic Investment in Transition Economies? // Economics of Transition and Institutional Change, vol. 27, no 1, pp. 163200. DOI: $10.1111 /$ ecot. 12184

Kalotay K. (2001). The Contribution of Foreign Direct Investment to Transi- tion Revisited // The Journal of World Investment, vol. 2, no 2, pp. 259-276. DOI: $10.1163 / 221190001 X 00266$

Kalotay K. (2004). Will Foreign Direct Investment Take Off in the Russian Federation? // The Journal of World Investment \& Trade, vol. 5, no 1, pp. 119-138. DOI: 10. 1163/221190004X00335

Kalotay K. (2010). Patterns of Inward FDI in Economies in Transition // Eastern Journal of European Studies, vol. 1, no 2, pp. 55-76 // http://ejes.uaic.ro/articles/ EJES2010_0102_KAL.pdf, дата обращения 16.05.2021.

Kalotay K. (2012). Indirect FDI // The Journal of World Investment \& Trade, vol. 13 , no 4 , pp. $542-555$. DOI: $10.1163 /$ $221190012 X 649841$

Kalotay K. (1) (2013). The 2013 Cyprus Bailout and the Russian Foreign Direct Investment Platform // Baltic Rim Economies - Bimonthly Economic Review, no 3/2013, pp. 58-59 // https://sites.utu.fi/ bre/wp-content/uploads/sites/227/ 2019/04/BRE_2013_3.pdf, дата обращения 16.05.2021.

Kalotay K. (2) (2013). FDI in the Former Soviet Periphery in Six Charts // AIB Insights, vol. 13, no 4, pp. 8-12. DOI: 10. 46697/001c.16942

Kalotay K. (2014). The Crimean Crisis and the Future of Russian Outward Foreign Direct Investment // Baltic Rim Economies - Bimonthly Economic Review, no 4/2014, pp. 24-26// https://papers.ssrn.com/sol3/papers.cfm?abstract_ $\mathrm{id}=2517313$, дата обращения 16.05.2021.

Kalotay K. (2015). Acquisitions as Engines of Foreign Expansion of Russian Multinationals // Handbook of Emerging Market Multinational Corporations (eds. Demirbag M., Yaprak A.), Cheltenham, Glos. - Northampton MA: Edward Elgar, pp. 239-259. DOI: 10.4337/ 9781782545019.00021

Kalotay K., Panibratov A. (2013). Crossborder M\&A and Competitive Advantage of Russian EMNEs // The Competitive Ad- 
vantage of Emerging Market Multinationals (eds. Williamson P.J., Ramamurti R., Fleury A., Leme Fleury M.T.), Cambridge: Cambridge University Press, pp. 220-238. DOI: $10.1017 / \mathrm{CBO} 9781139506694.018$

Kalotay K., Sulstarova A. (2010). Modelling Russian Outward FDI // Journal of International Management, vol. 16, no 2, pp. 131-142. DOI: 10.1016/j.intman. 2010.03.004

Kalotay K., Sulstarova A. (2013). LongTerm Prospects of Inward Foreign Direct Investment in the Baltic Sea Region // Journal of East-West Business, vol. 19, no 1-2, pp. 79-90. DOI: 10.1080/10669868. 2013.780500

Kinoshita Y., Campos N.F. (2003). Why Does FDI Go Where it Goes? New Evidence from the Transition Economies // IMF Working Paper. no 03/228 // https://www.imf.org/en/Publications/WP/ Issues/2016/12/30/Why-Does-Fdi-GoWhere-it-Goes-New-Evidence-From-theTransition-Economies-16954, дата обращения 16.05.2021.

Kononov O. (2010). Ukraine's Inward FDI and Its Policy Context // Columbia FDI Profiles, April 13, 2010. DOI: 10.7916/ D8VM4K3W

Kuznetsov A. (1) (2010). Inward FDI in Russia and Its Policy Context // Columbia FDI Profiles, June 30, 2011. DOI: 10.7916/ D82232NT

Kuznetsov A.V. (2) (2010). Urgent Tasks for Research on Russian TNCs // Transnational Corporations, vol. 19, no 3, pp. 81-95. DOI: 10.18356/a4d8cef8-en

Kuznetsov A. (2011). Russia: Outward FDI and Its Policy Context, Update 2011 // Columbia FDI Profiles, August 2, 2011 // https://ssrn.com/abstract=2337449, дата обращения 16.05.2021.

Kuznetsov A. (2012). Inward FDI in Russia and Its Policy Context // Columbia FDI Profiles, September 4, 2012. DOI: 10.7916/D82J6M2S

Kuznetsov A.V. (2013). Monitoring of Direct Investments of Belarus, Kazakh- stan, Russia and Ukraine in Eurasia // EDB Centre for Integration Studies. Report no 19 // https://eabr.org/upload/iblock/ d7a/report_19_en_preview.pdf, дата обращения 16.05.2021.

Kuznetsov A.V. (2016). Russian Direct Investment as a Factor of Eurasian Integration // Problems of Economic Transition, vol. 58, no 4, pp. 348-361. DOI: 10.1080/10611991.2016.1222802

Kuznetsov A.V. (2020). Foreign Direct Investment // International Encyclopedia of Human Geography (ed. Kobayashi A.), Amsterdam: Elsevier, pp. 219-227. DOI: 10.1016/B978-0-08-102295-5.10070-8

Kuznetsov A.V. (2021). Direct Investment from Russia Abroad: Changes since 2018 // Istoriya, no 21, pp. 9-15. DOI: 10.18254/S207987840015225-6

Kuznetsov A., Baronina Y., Volodina M., Gemuyeva K., Kvashnin Y., Lukonin S., Makarova A., Nevskaya A., Frumkin B., Chetverikova A., Shchedrin A. (2017). EAEU and Eurasia: Monitoring and Analysis of Direct Investments // EDB Centre for Integration Studies. Report no 47 // https://russiancouncil.ru/upload/iblock/ 7c4/edb-centre_2017_report-47_fdi-eurasia_eng.pdf, дата обращения 16.05.2021.

Kuznetsov A.V., Kvashnin Y.D., Gutnik A.V. (2013). Monitoring of Mutual Investments in the CIS // EDB Centre for Integration Studies. Report no 15 // https://www. imemo.ru/files/File/en/publ/2013/13015_ en.pdf, дата обращения 16.05.2021.

Kuznetsov A.V., Kvashnin Y.D., Gutnik A.V., Slesareva K.V. (1) (2014). Monitoring of Mutual Investments in the CIS Countries-2014 // EDB Centre for Integration Studies. Report no 26. DOI: 10.2139/ ssrn.2524050

Kuznetsov A.V., Kvashnin Y.D., Lukonin S.A., Chetverikova A.S., Shchedrin A.V. (2) (2014). Monitoring of Direct Investments of Russia, Belarus, Kazakhstan and Ukraine in Eurasia - 2014 // EDB Centre for Integration Studies. Report no 28. DOI: $10.2139 /$ ssrn.2554961 
Kuznetsov A.V., Nevskaya A.A. (2017). Geography of FDI from Visegrad Countries in Russia // Bulletin of Geography. Socio-economic Series, no 36, pp. 107 115. DOI: $10.1515 /$ bog-2017-0018

Ledyaeva S., Karhunen P., Whalley J. (2013). Offshore Jurisdictions (including Cyprus), Corruption Money Laundering and Russian Round-trip Investment // National Bureau of Economic Research Working Paper Series. no 19019 // http:// www.nber.org/papers/w19019, дата обращения 16.05.2021.

Liuhto K. (ed.) (2006). Expansion or Exodus? Why Do Russian Corporations Invest Abroad? Binghamton NY: International Business Press //https://www.routledge. com/Expansion-or-Exodus-Why-Do-Russian-Corporations-Invest-Abroad/Liuhto/ p/book/9780789032867, дата обращения 16.05.2021.

Liuhto K. (2015). Motivations of Russian Firms to Invest Abroad: How Do Sanctions Affect Russia's Outward Foreign Direct Investment? // The Baltic Region, no 4(26), pp. 4-19. DOI: $10.5922 / 2079$ 8555-2015-4-1

Liuhto K., Majuri S. (2014). Outward Foreign Direct Investment from Russia: A Literature Review // Journal of East-West Business, vol. 20, no 4, pp. 198-224. DOI: 10.1080/10669868.2014.967434

Liuhto K., Sutyrin S., Blanchard J.-M.F (eds.) (2017). The Russian Economy and Foreign Direct Investment, Abingdon, Oxon - New York: Routledge. DOI: 10. 4324/9781315651101

Liuhto K., Vahtra P. (2007). Foreign Operations of Russia's Largest Industrial Corporations - Building a Typology // Transnational Corporations, vol. 16, no 1 , pp. 117-144//https://digitallibrary.un.org/ record/605091? ln=en, дата обращения 16.05.2021.

McCarthy D.J., Puffer S.M., Satinsky D.M. (2019). Will Russia Have a Role in the Changing Global Economy? Contrasting Western and Russian Cultural
Lenses // Cross Cultural \& Strategic Management, vol. 26, no 2, pp. 265-289. DOI: 10.1108/CCSM-10-2018-0164

Okafor G., Webster A. (2016). Foreign Direct Investment in Transition Economies of Europe and the Former Soviet Union // Palgrave Dictionary of Emerging Markets and Transition Economics (eds. Hölscher J., Tomann H.), Houndmills, Basingstoke: Palgrave Macmillan, pp. 413434. DOI: 10.1007/978-1-137-37138-6_22

Panibratov A. (2012). Russian Multinationals: From Regional Supremacy to Global Lead, Abingdon, Oxon - New York: Routledge // https://www.routledge.com/ Russian-Multinationals-From-Regional-Supremacy-to-Global-Lead/Panibratov/p/book/9780415731348, дата обращения 16.05.2021.

Panibratov A. (2016). Home Government Influence on Russian MNEs: Balancing Control against Interest // International Journal of Emerging Markets, vol. 11, no 4, pp. 474-496. DOI: 10.1108/ IJoEM-11-2014-0193

Panibratov A., Kalotay K. (2009). Russian Outward FDI and Its Policy Context // Columbia FDI Profiles, October 13, 2009. DOI: 10.7916/D84173W5

Panibratov A., Michailova S. (2019). The Role of State Ownership and Home Government Political Support in Russian Multinationals' Internationalization // International Journal of Emerging Markets, vol. 14, no 3, pp. 436-450. DOI: 10.1108/ IJOEM-10-2017-0380

Pelto E., Vahtra P., Liuhto K. (2004). Cyp-Rus Investment Flows to Central and Eastern Europe - Russia's Direct and Indirect Investments via Cyprus to CEE // Journal of Business Economics and Management, vol. 5, no 1, pp. 3-13. DOI: 10 . 1080/16111699.2004.9636063

Sauvant K.P. (2006). Inward and Outward FDI and the BRICS // Emerging Economies and the Transformation of International Business: Brazil, Russia, India and China (BRICs) (ed. Subhash C. Jain), 
Cheltenham, Glos. - Northampton MA: Edward Elgar, pp. 313-409. DOI: 10.4337/ 9781847202987.00024

Tepavcevic S. (2015). The Motives for Russian State-owned Companies for Outward Foreign Direct Investment and Its Impact on State-Company Cooperation: Observations Concerning the Energy Sector // Transnational Corporations, vol. 23, no 1, pp. 29-58. DOI: $10.18356 / 2$ cca1166-en

Transparency International (2020). Corruption Perceptions Index 2020, Berlin: Transparency International // https:// www.transparency.org/en/cpi/2020/in$\mathrm{dex} / \mathrm{nzl}$, дата обращения 16.05.2021.

UNCTAD (2002). World Investment Report 2002: Transnational Corporations and Export Competitiveness, New York and Geneva: United Nations.

UNCTAD (2018). World Investment Report 2018: Investment and New Industrial Policies, New York and Geneva: United Nations.

UNCTAD (2020). World Investment Report 2020: International Production beyond the Pandemic, New York and Geneva: United Nations.

UNCTAD (2021). World Investment Report 2021: Investing in Sustainable Recovery, New York and Geneva: United Nations.

UN.ECE (2001). Chapter 5: Economic Growth and Foreign Direct Investment in the Transition Economies // Economic Survey of Europe, no 1, pp. 185-225 // https:// digitallibrary.un.org/record/443369?1$\mathrm{n}=\mathrm{en}$, дата обращения 16.05.2021.
United Nations (1992). World Investment Directory 1992: Central and Eastern Europe,New York:United Nations//https:// digitallibrary.un.org/record/158036? $\ln =e n$, дата обращения 16.05.2021.

Vahtra P., Liuhto K. (2006). An Overview of Russia's Largest Corporations Abroad // Journal of East-West Business, vol. 11 , no $3-4$, pp. $23-40$. DOI: $10.1300 /$ J097v11n03_03

Weiner C. (2018). International Expansion of Russian Multinationals: A Focus on Home-country Push Factors, Europe and Five CEE Countries // Centre for Economic and Regional Studies HAS Institute of World Economics Working Paper. no 250. DOI: 10.13140/RG.2.2.13322.36808

Weiner C. (2020). Russian Multinational Direct Investment in East Central European Countries // Emerging-market Multinational Enterprises in East Central Europe (ed. Szunomár Á.), Cham: Palgrave Macmillan, pp. 153-195. DOI: 10. 1007/978-3-030-55165-0_6

Zabortseva Y.N. (2014). Rethinking the Economic Relationship between Kazakhstan and Russia // Europe-Asia Studies, vol. 66, no 2, pp. 311-327. DOI: 10.1080/ 09668136.2013 .872333

Zavyalova E.B., Tkachev V.N., Berezko V.E., Perepelkin A.N. (2019). Trends and Issues in Economic Relations of Cyprus and Russia // The Cyprus Review, vol. 31, no 3, pp. 139-157 // http://cyprusreview.org/index.php/cr/article/view/672, дата обращения 16.05.2021. 